$K$
$(200)$
$600 \cdot 246$
Bulletin No. 246

DEPARTMENT OF THE INTERIOR

UNITED STATES GEOLOGICAL SURVEY

CHARLES D. WALCOTT, DIRECTOR

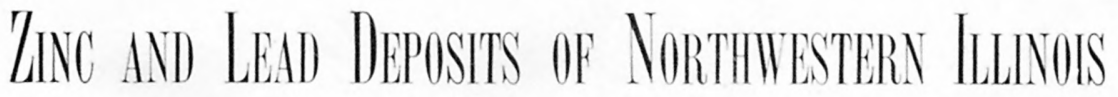

BY

H. FOSTER BAIN

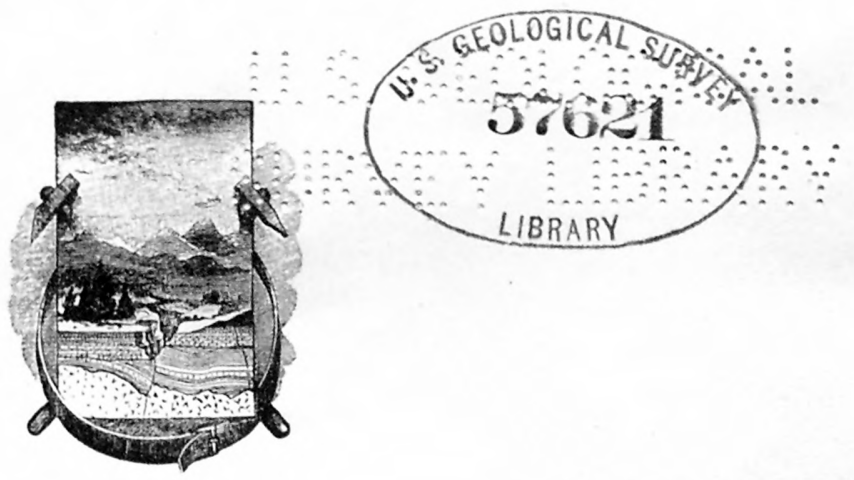

WASHINGTON

GOVERNMENT PRINTING OFFICE 



\section{0 N T E N T S.}

\section{Tetter of tramsmittal}

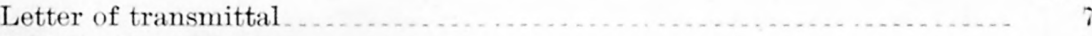

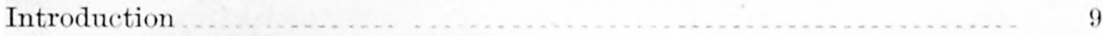

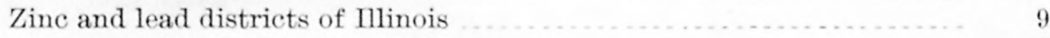

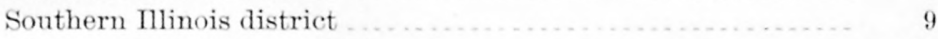

Northwestern Illinois district ... . . . . . . . . . . . . . . . . 10

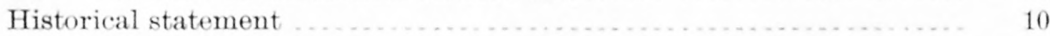

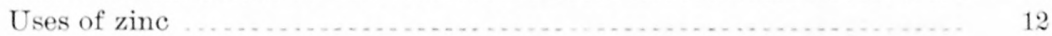

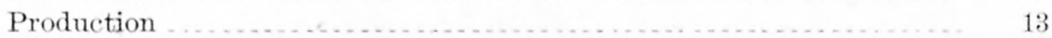

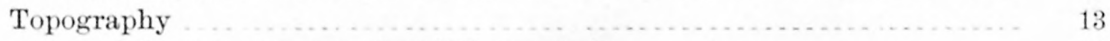

Niagara escarpment and the mounds ....................... 14

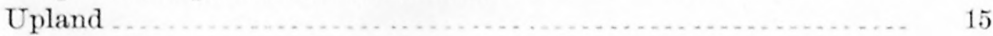

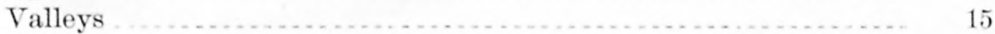

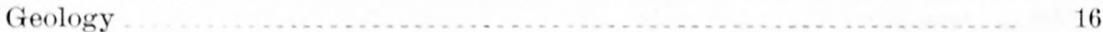

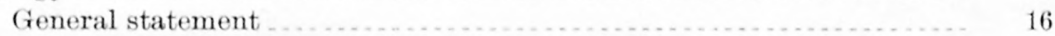

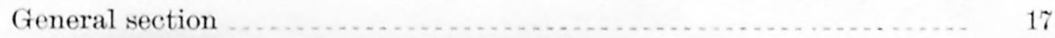

Pre-Cambrian rocks . . . . . . . . . . . . . . . . . . . . . . . . . . . . $\ldots \ldots \ldots$

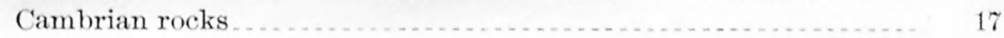

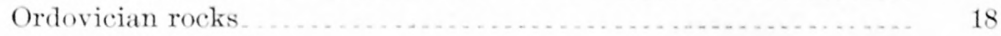

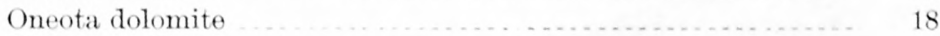

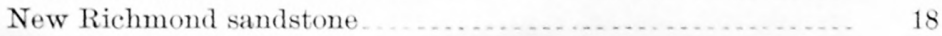

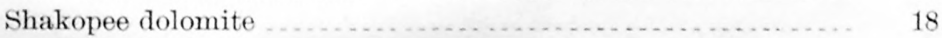

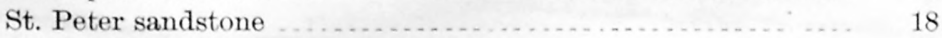

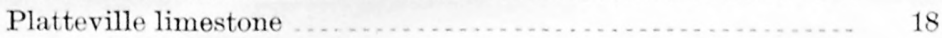

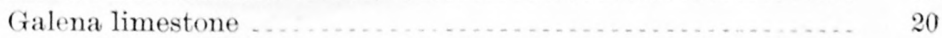

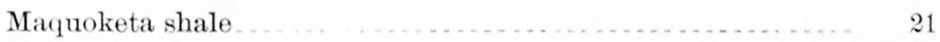

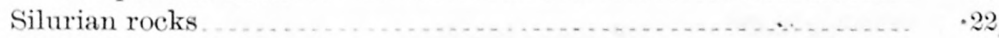

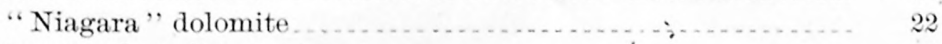

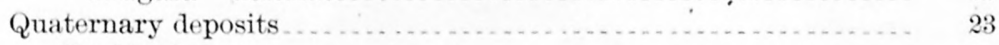

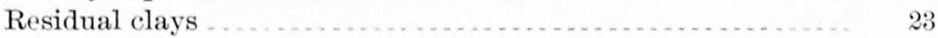

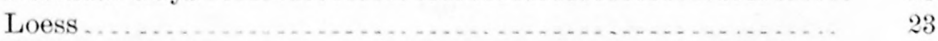

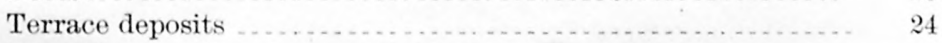

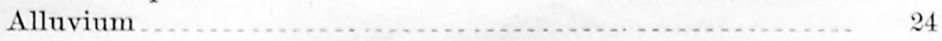

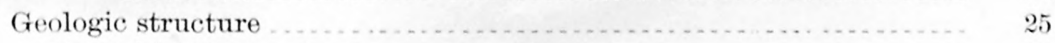

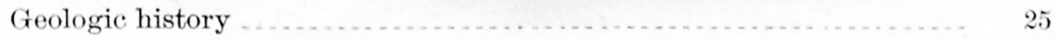

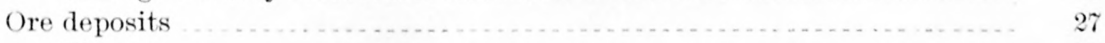

The ores

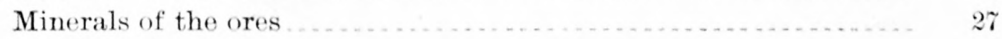

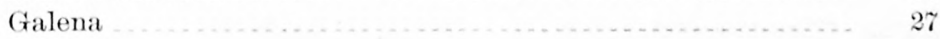

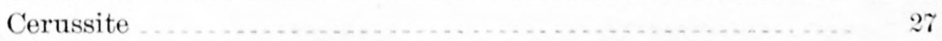

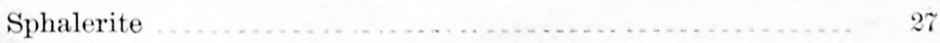

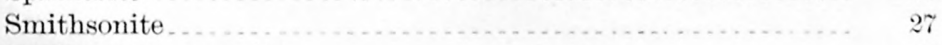

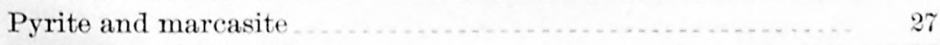

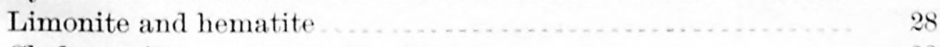

Chalcopyrite ...... 


$$
\text { ta }
$$


Ore deposits-Continued.

The ores-Continued.

Minerals of the ores-Continued.

Malachite and azurite

Page.

Barite _............................ 28

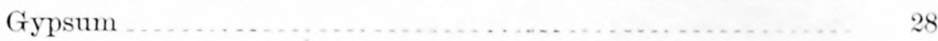

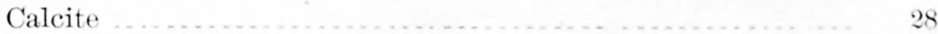

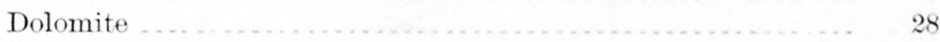

Wad _...... 28

Less abundant minerals _... _....... 28

Paragenesis _......................... 29

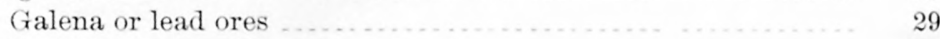

Smithsonite or zinc-carbonate ores _................ 30

Blende or zinc-sulphide ores ............................ 30

Mode of occurrence ...... _... 30

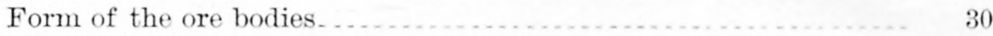

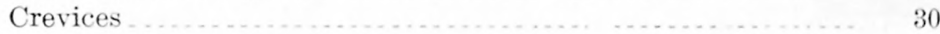

Definition ..... 30

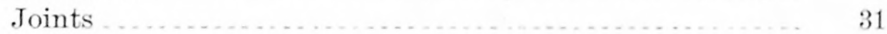

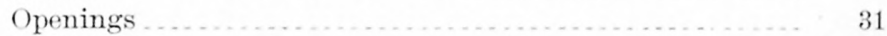

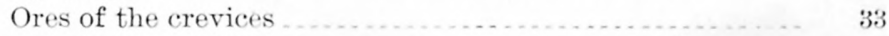

Flats and pitches …

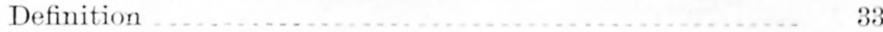

Illustration …

Position ..................... 34

Ores of the flats and pitches _.................. 34

Importance . . . . . . 35

Relations of the ore bodies to structure . . . . . . . . . . . . . . . . . . 35

Relations of the ore bodies to topography _................ 35

Relations of the ores to underground water level _........... 35

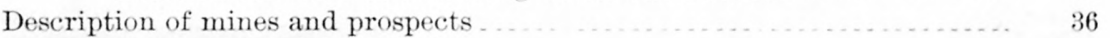

General statement _.............. 36

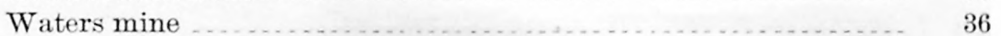

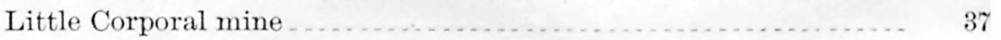

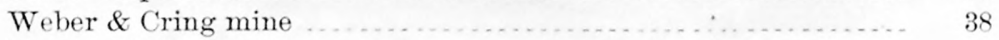

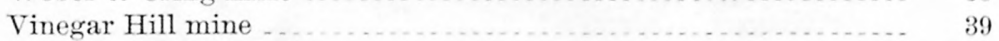

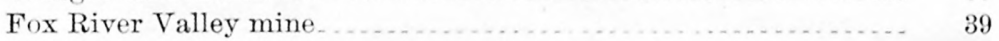

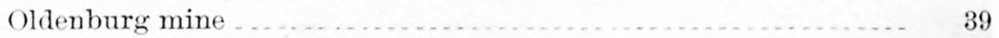

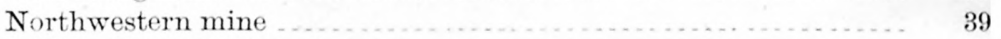

California or Sand Prairie mine _.................. . . . . . 40

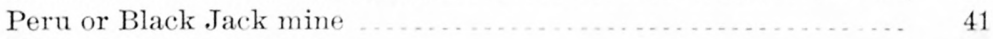

Wishon mine ..... ....... 43

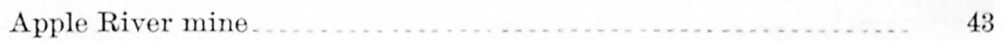

Skene mine ............................... 43

Queen mine ........................................ 44

Vista Grande mine _.................................. 44

Origin of the deposits ...................... 44

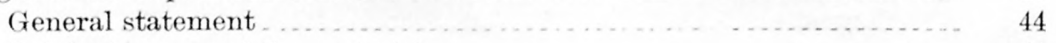

Original source of the material _......

Process of concentration _...

Local circulation .................. 46

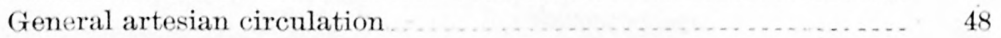

Future development . . . . . .

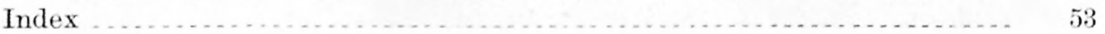




\section{ILLUSTRATIONS.}

Plate I. Map showing relations of the zinc district to coal fields and smelting centers . . . . . . . . .

II. Map showing general geology of the upper Mississippi region...

III. Geologic map of the zinc and lead district of northwestern Illinois

IV. Weathered surface of the Galena limestone near Rockdale, Iowa

Page.

V. $A$, Oblique and vertical joints in Galena limestone at East Dubuque; $B$, Crevices and openings in Galena limestone at East

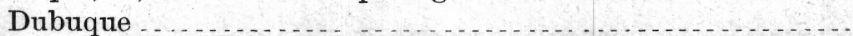

Fig. 1. The mounds, upland, and river terrace, as seen from Galena, Ill. looking southeast . . . . .

2. Vertical east-west section along the McNulty crevice, Avenue Top mine

3. Plan and cross sections of the Empress mine 



\title{
LETTER OF TRANSMITTAL.
}

\author{
DePaRTMENT OF THE INTERIOR, \\ United States Geological Survey, \\ Washington, D. C., June 1, 1904.
}

SIR: I have the honor to transmit herewith the manuscript of a report entitled "Zinc and Lead Deposits of Northwestern Illinois," by H. Foster Bain, and to recommend its publication as a bulletin. While this is preliminary to the final report contemplated for the upper Mississippi Valley, it is complete for the lead and zinc district in Illinois.

Very respectfully,

C. W. HAYES,

Hon. Charles D. Walcott, Geologist in Charge of Geology.

Director United States Geological Survey. 




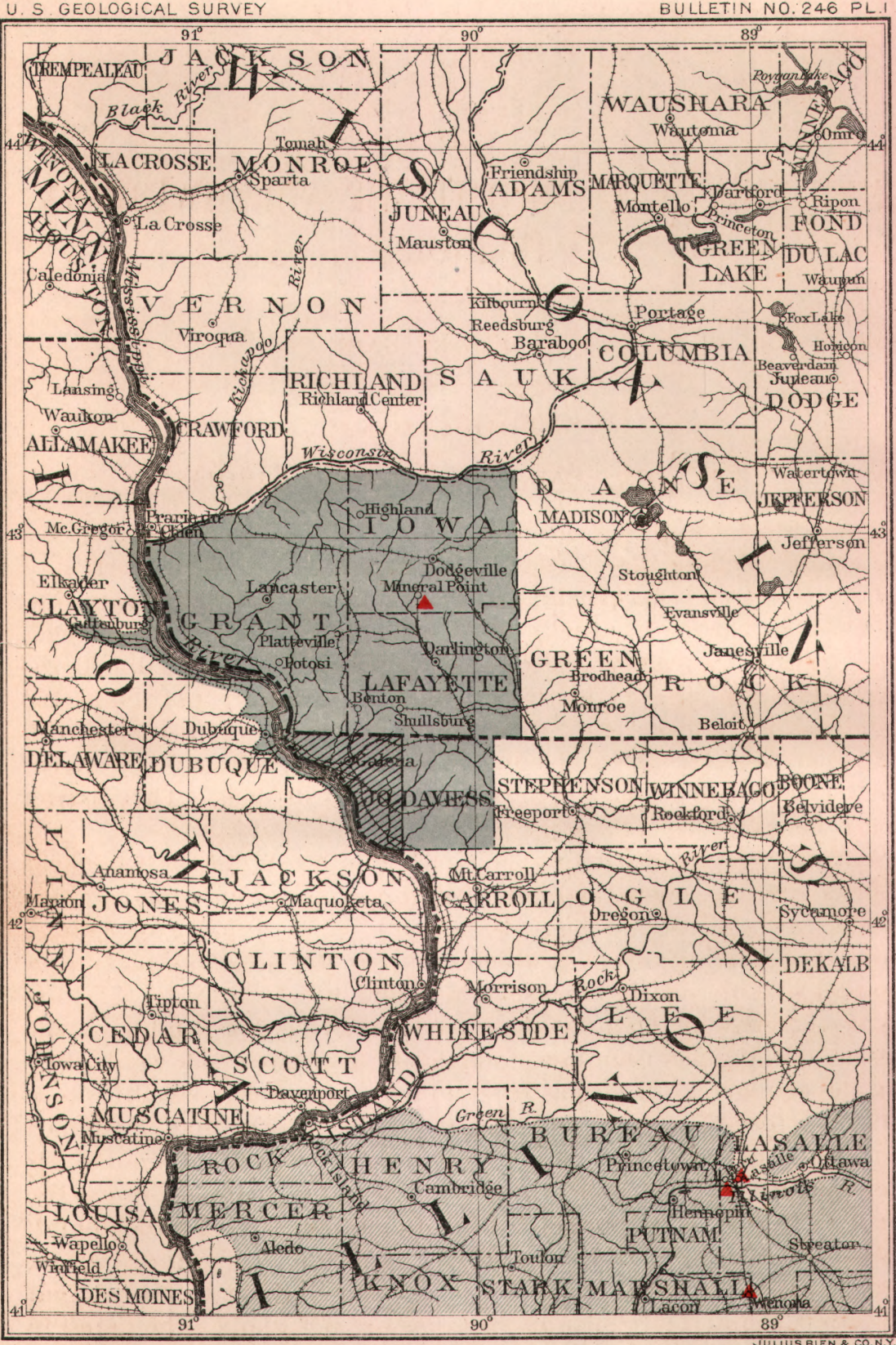

MAP SHOWING RELATIONS OF ZINC DISTRICT TO COAL FIELD AND SMELTERS

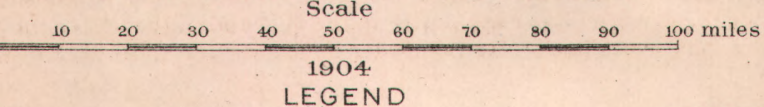

Zinc district

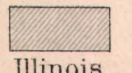

coal field

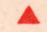

Smelter

and oxide works special map 


\section{ZINC AND LEAD DEPOSITS OF NORTHWESTERN ILLINOIS.}

By H. Foster Bain.

\section{INTRODUCTION. $a$}

\section{ZINC AND LEAD DISTRICTS OF ILLINOIS.}

Zinc and lead minerals are found in two widely separated districts in Illinois. One of these occurs in the extreme southern portion of the State and includes portions of Hardin, Pope, and Saline counties. It forms part of the Kentucky-Illinois fluorspar, lead, and zine field, and for convenience may be referred to as the Southern Illinois district. The other occurs in the extreme northwestern portion of the State and includes a part of Jo Daviess County. It is included in the upper Mississippi Valley zine and lead field and may be conveniently referred to as the Northwestern Illinois district. This district forms the subject of this paper.

Southern Illinois district.-The Southern Illinois district has never yielded zine in commercial quantity, though small amounts of both blende and smithsonite have been found at a number of points. From that part of the field which occupies the adjacent portion of Kentucky zine ore has for several years been shipped. The ore has been found in quantity at only one or two points, and up to the present nothing has been found north of the Ohio which would warrant development. Lead has been mined more or less steadily since 1842 , but for some years the output has been small and irregular. Probably the maximum production was in 1866-67, when 176,387 pounds were shipped by the Fairview mine. T'he principal ore of the southern district is fluorspar, and the production of lead is incidental. A separate discussion of the fluorspar deposits is now in preparation, and it will be sufficient to indicate here the author's opinion that important amounts of zinc and lead ores are not likely to be found in

\footnotetext{
$a$ In the preparation of this report the author is under many obligations to Messrs. E. E. Ellis and A. F. Crider for field assistance and to Dr. U.S. Grant, of the Wisconsin Geological and Natural History Survey, for cooperation both in the field and in the office. In the discussion of the Platteville formation in particular Doctor Grant's notes and those of Mr. E. O. Ulrich have been freely used.
} 
this area. In 1903 prospecting for lead was being carried on west of the main district, near Jonesboro, in Union County. Some galena was found, but whether in paying quantities has not yet appeared.

Northwestern Illinois district.-The mines and prospects of northwestern Illinois occur altogether within Jo Daviess County, and the majority of them are found within a very few miles of either Galena or Elizabeth. The formation in which the ore occurs extends somewhat more widely, underlying much of the State north of the coal fields and west of a north-south line drawn through Dekalb. Most of that territory is heavily covered with drift, and there are comparatively few outcrops outside of Jo Daviess County, which lies in the driftless area. In Stephenson County galena has been noted at a few points, but no ore bodies have been developed.

The Northwestern Illinois district forms a portion only of the upper Mississippi zinc and lead field, which lies mainly in Wisconsin, but includes parts of Illinois and Iowa. The field, as a whole, includes approximately 4,000 square miles. Within it ore has been mined for many years in a number of scattered areas, which include a relatively small portion of the whole. In the Northwestern Illinois district ore is now being mined or prospected for upon twenty to twenty-five separate sections of land. These are scattered through an area of approximately 150 square miles, which may be fairly eonsidered to be within the proved ore-bearing district. With a less degree of probability, the whole of Jo Daviess County may be considered as within the mineral field. The general situation of the district is indicated in $\mathrm{Pl}$. I.

While the portions of the upper Mississippi field that lie in Iowa and Illinois are relatively small when compared with the extent of the field in Wisconsin, they include some of the richest of the territory, and for many years Galena and Dubuque were the most important shipping points in the region.

\section{HISTORICAL STATEMENT.}

The upper Mississippi mines were among the first within the United States to produce large quantities of ore, and for many years they afforded the chief supply of lead produced in this country. The discovery of lead ore in this region has been doubtfully ascribed to Nicolas Perrot about 1692, but it was more probably Le Sueur, who first noted its presence in the course of his voyage up the Mississippi in 1700, or possibly on an earlier voyage. The Indians had doubtless known of its occurrence before, and as early as 1690 they brought some of the ore to the French traders at Peoria. They made no effort to mine it regularly until later. The first mining was done in Iowa, by Julien Dubuque, who, between the years 1788 and 1810, lived among the Indians and with their help opened mines within the limits of the city which takes its name from him. After Dubuque's death the 
Indians continued to take out ore, selling it to traders who maintained, a post upon one of the islands in the river. In 1820, when the area was visited by Schoolcraft, ${ }^{a}$ mining was being carried on at four points, two of which were in Iowa and two in Illinois. The Iowa mines were on the Maquoketa, probably where Durango is now located, and within the present limits of Dubuque. In Illinois the mines were on Sinsinawa and Fever (now Galena) rivers, and marked the beginning of mining near Galena.

By act of Congress of March 3, 1807, all Government lands containing lead ore were reserved from sale and a system of leasing was adopted. No leases were issued, however, prior to $1822,{ }^{b}$ and little mining was done up to 1826 . Within the succeeding five years dișcoveries were made at many points and production increased with great rapidity. In 1834 the leasing system was done away with, and in 1839, preliminary to the sale of the lands, Dr. David Dale Owen made the first geologic survey of the district. This survey was carried out with a hastily collected force of 139 assistants, who, between September 17 and November 24, examined every quarter section in the district. In the map accompanying this report ${ }^{c}$ lead was marked as occurring at eight points in Illinois, including practically all the localities now known. The period of greatest productivity: is stated by Whitney ${ }^{d}$ to have been between 1840 and 1850 , with a maximum in 184. . In 1852 the region is estimated to have produced 13,000 tons of lead, an amount equal to 10 per cent of the world's production and 87 per cent of the American output of that year. Lead mining in the region continued to be important up to the opening of the rich silver-lead mines of the Western States in the early sixties. It then rapidly decreased, and for some years the production has been unimportant, amounting to approximately 1,000 tons per annum.

The zinc ores were early recognized, but were long of no value. Owen, in his survey of 1839 , noted their presence at many points, and Whitney, in his various publications ${ }^{e}$ on the district, discussed the occurrence and possible reduction of the ore. In the early days of lead mining the zine ore was considered not only of no value, but as a positive nuisance, by the miners. The first attempt to utilize it was made by Matthiessen \& Hegeler, who, after some preliminary experiments, erected works at Lasalle, Ill., in 1852. In 1859 the manufacture

a Schoolcraft, H. R., Narrative Journal of Travels, etc., 1821, pp. 340-354,

$b$ Whitney, J. D., Rept. Geol. Survey Upper Mississippi Lead Region, 1862, p. 80.

c Owen, David Dale, Rept. geol. explor. part of Iowa, Wisconsin, and Illinois, etc.: H. Doc. 239, 26th Cong., 1st sess, 1840; S. Doc. 407, 28th Cong., 1st sess., 1844.

dGeol. Survey Illinois, vol. 1, 1866, p. 156.

$e$ Metallic Wealth of the United States, 1854, p. 352. Geol. Survey Iowa (Hall), vol. 1, pt. 1, 1858, pp. 469-471. Geol. Survey Wisconsin (Hall), vol.1, 1862, pp. 73-420. Geol. Survey Illinois (Worthen), vol. 1, 1866, pp. 153-207. Rept. Geol. Survey Upper Mississippi Lead Region, 1862, 455 pages; a reprint separately bound of the portions of the Wisconsin report dealing with the lead region. 
of oxide began at Mineral Point, Wis., and in 1870 the Illinois Zine Company erected its plant at Peru, Ill. These three plants are now the main users of zinc ore from the district. A limited amount is shipped to Waukegan, Ill., and at various times in the past small amounts have gone to the zine furnaces in Indiana.

Since 1860 there have been steady shipments of zine ore from the district as a whole, and in certain years the Illinois mines have contributed a notable portion of the product. At first only the carbonate ores were used, but eventually means were found for economically roasting the sulphide ores, and a demand for them was created. The discovery of the rich deposits at Joplin satisfied this demand, and up to the period of high prices beginning in 1899 there was but a limited market for the blende produced in the upper Mississippi region. The ores carry a notable amount of iron sulphide and can be used in ordinary zine retorts only when mixed in small quantity with the richer Joplin ores. The development, however, of the method of cleaning the ores by roasting and magnetic separation, as well as the addition of an acid plant to the oxide works of the Mineral Point Zine Company, has stimulated production and attracted renewed attention to the field. At present the output of zinc ore is increasing, although the output of lead continues to be insignificant.

\section{USES OF ZINC.}

Zine is a blue-gray to white metal having a specific gravity of 6.86 to 7.3 , as determined by various observers and depending somewhat upon its condition. Its most important uses result from certain properties peculiar to itself or developed in it to an unusual degree. Between temperatures of $100^{\circ}$ and $150^{\circ} \mathrm{C}$. it is capable of being rolled into very thin sheets. It melts at a low temperature, $412^{\circ}$ to $434^{\circ} \mathrm{C}$., and volatilizes at about $1,000^{\circ} \mathrm{C}$. It readily oxidizes, forming under proper conditions a fine white powder. It has fair electrical conductivity, and is the most important negative metal. It alloys readily with the common metals, forming with copper a number of alloys familiarly known as brass.

Zine was not recognized as an independent metal until the thirteenth century, and means for its reduction were not found until long after. ${ }^{a}$ In the middle of the eighteenth century works were established in Europe. In America zine was first manufactured at the Washington Arsenal in 1838. The regular manufacture of spelter was not taken up until 1858-1860, although oxide works were established in $1851 .^{b}$ In $1903,59,562^{c}$ short tons of zinc oxide and 159,219 tons of spelter were manufactured. The most important use for spelter is in galvanizing. In Mineral Industry for 1899, volume 8,

a Ingalls, W. R., Production and Properties of Zinc, 1902, pp. 1-6.

IIngalls, op. cit., p. 14.

-Kirchhoff, Charles, Mineral Resources of the United States, 1903, advance extract, p. 4. 
it is estimated that 50 per cent of the spelter produced was used for this purpose. The same authority states that 20 per cent was rołled into sheets, 15 per cent used in the manufacture of brass, and the remainder sold for a wide variety of minor uses.

The character of an ore determines to some extent the process by which it may be reduced and the use which is made of the metal. Under economic conditions obtaining up to the last year or so the carbonates, oxides, and silicates only were used in the manufacture of zinc oxide. At present sulphides as well as carbonates can be used at the oxide works. At an earlier period the carbonates and silicates only were used for spelter production, but blende has long been the main ore used for that purpose, and lower and lower grades of sulphide ores are finding buyers. Until about five years ago the upper Mississippi mines produced zine carbonate principally, but now the main output is blende, though carbonate is still shipped.

\section{PRODUCTION.}

It is impossible to give accurate figures for either the present or the total production of the Illinois mines. The production of the upper Mississippi mines as a whole has been reviewed by Winslow. ${ }^{a}$ By the use of the figures he has compiled and the best estimates for recent years obtainable it may be roughly computed that the total production of zinc ore has been 425,000 short tons. For the last five years the output has rapidly increased, and is now somewhat more than 20,000 tons a year. In 1903 approximately 1,000 tons of zinc ore were sold by the Illinois mines. In the same year the mines of the Missouri-Kansas district sold 227,689 tons of ore, and the total output of the United States in tons of spelter was 159,219. If a general average of 60 per cent of zinc be allowed in this ore and smelting losses be put at 20 per cent, this would be approximately equivalent to 325,000 tons of ore. Accordingly, from the point of view of present production, the mines of this area are relatively unimportant. It is believed, however, that in the future this district will play a larger rôle in supplying zinc furnaces. It is hardly to be expected that American furnaces will continue indefinitely to obtain the exceptionally high-grade concentrates which it is their good fortune to handle at present, and, with increasing demand for lower grades and the wider utilization of improved processes already perfected, the excellent situation of the upper Mississippi fields will commend them to development.

\section{TOPOGRAPHY.}

The lead and zine deposits of the upper Mississippi lie within the well-known driftless area. The region is one which seems exceedingly rugged when contrasted with the smooth drift-covered plains 
that surround it. There is a total relief of about 500 feet, the bottom lands of the Mississippi lying about 600 feet above sea level, and the tops of the highest hills rising a little above the 1,100-foot contour. The dominant topographic feature of the region is an upland plain lying about 900 feet above the sea in the southern portion of the area and rising gently toward the north. Below this plain the rivers have cut their valleys, while above it rise a number of detached hills, locally known as mounds, and a well-defined escarpment, which bounds it to the southeâst and the southwest. From the fact that this escarpment is made by the outcropping edge of the hard chert and dolomite of the Niagara it may fittingly be called the Niagara escarpment.

\section{NIAGARA ESCARPMENT AND THE MOUNDS.}

The most striking and picturesque features of the landscape are the mounds and the frowning range of hills which hem in the district on the south. Viewed from the higher portions of the city at Galena, the isolated mounds southeast of the city, with the high rampart beyond Smallpox Creek in the background, are very impressive (fig. 1, p. 24). From Dubuque a similar view may be had to the southwest. From almost every point upon the great upland plain of the region either these encircling hills or some one of the detached mounds may be seen. The Illinois portion of the area has not yet been covered by topographic mapping, so that the height of the escarpment is undetermined. Horseshoe Mound, the nearest outlying hill, rises 430 feet above the Burlington Railway station at Galena, or to an altitude of 1,030 feet, according to observations of the Mississippi River Commission. Southwest of Dubuque the escarpment itself rises approximately 100 feet higher.

Viewed in a large way, the escarpment has an abrupt slope facing the mining district, and a long gentle back slope away from it. To the south and west this back slope descends so gradually as to escape attention until it reaches the same altitude as the plain to the north which the escarpment overlooks. In Illinois the back slope, owing to the encroachment of streams from the south, is less well defined, particularly in the area under survey. Apple River and its tributaries have cut back so vigorously that only a narrow ridge is left between its basin and that of Smallpox Creek, which lies to the north. Between Smallpox and Galena rivers a series of disconnected mounds mark the position of an earlier and still more completely dissected escarpment front.

Southeast of Smallpox Creek the escarpment shows in a somewhat irregular front with a general trend paralleled by the stream. It culminates in a narrow ridge about 2 miles from the stream. Southeast of this divide the ridge extends out in long, finger-like processes between the various tributaries of Apple River, which lies 7 to 8 miles 
away. The divide therefore is asymmetric, with a short and a long arm, the former facing the plain and the latter corresponding to the general back slope so well defined in Iowa. These general relations are shown on the geologic map accompanying this report, the area covered by the Niagara marking the position of the escarpment and . the mounds.

To the north the escarpment faces the upland plain upon which the Horseshoe and Sinsinawa mounds, the Platte Mounds, the Blue Mounds, and other isolated hills are scattered. The area occupied by these mounds is small as compared with the total area of the plain. The distances between them are great and their diameters are small: Their tops rise to the level of the escarpment, and a plane projected from the crest of the latter and touching the top of the mounds would be approximately even and would rise gently to the northeast.

\section{UPLAND.}

The plain above which these mounds rise is the most important physiographic feature of the region. It is well displayed at Galena, Dubuque, Platteville, and at various points as far north as the Military Ridge, along which the La Crosse division of the Chicago and Northwestern Railway runs. From Monfort to Cuba the Galena line of the same railway traverses it. The mounds rise 200 feet above it, and the streams have cut into it for 200 to 300 feet. It is a nearly even plain of subaerial erosion beveling the edges of both hard and soft strata-a peneplain. It marks a period in geologic time when the region stood at low level sufficiently long for the streams to reduce almost the whole area to this plain. The mounds are monadnocks and represent interstream areas which were not completely reduced.

'The whole of the upland is drained. The streams form a network covering every part of it and make up a normal dendritic drainage system.

\section{VALLEYS.}

The upland plain is everywhere cut by valleys, and while in general it forms a nearly level surface, in detail it is made up of a multitude of slopes facing the streams. The most important stream in the area is the Mississippi, the major tributaries of which in Illinois are Apple River, Smallpox Creek, Galena River, Sinsinawa River, Menominee River, and Little Menominee River. The Mississippi flows in a sharp. walled valley having an even width slightly exceeding 1 mile. The bottom land lies about 600 feet above sea level and the walls rise abruptly to 750 or 800 feet. Back of this a gentler slope brings the surface up to the general level. The size of the Mississippi Valley is, in this district, out of proportion to that of its main tributaries. Its sharp walls are also exceptional; between two tributaries of one of the 
smaller streams the upland reaches out in a long, finger-like promontory; between two tributaries of the Mississippi there is, instead, a sharp canyon wall, as if there had existed promontories which later were truncated half or three-quarters of a mile back from the main stream. These features are excellently represented on the Elkader, Lancaster, and Peosta topographic sheets of the United States Geological Survey. They indicate that Mississippi River has had a history different from that of the other rivers of the region-a difference due to conditions existing in the Glacial epoch by reason of which certain streams heading outside of the driftless area received during the melting of the ice large volumes of water, while those within the area had only the normal flow. The minor streams of the area have near their headwaters broad, open valleys, where theslopes of the uplands and the slopes of the valley sides merge in long, beautiful, convex curves. In their lower portions they often have canyonlike phases and well-developed though narrow flood plains. The larger streams joining the Mississippi are marked by a well-defined aggradation terrace. The outer limits of this terrace are indicated on the geologic map.

\section{GEOLOGY.}

\section{GENERAL STATEMENT.}

The geology of northwestern Illinois is simple. Its main outlines were stated many years ago by Whitney, ${ }^{a}$ and additional details were given in 1873 by James Shaw. ${ }^{b}$

In the voluminous literature relating to the mines of Wisconsin and Iowa ${ }^{c}$ there is much which bears upon the Galena subdistrict. The region is one of unmetamorphosed, little-disturbed, sedimentary rocks of Paleozoic age, and there are no igneous rocks in or near it. In this it stands in sharp contrast with most other districts in which sulphide ores are important. Within the subdistrict now under review only Ordovician and Silurian beds occur. In order, however, to make the relations clear it seems advisable to review briefly the section found in the upper Mississippi region as a whole.

The section includes representatives of the Cambrian, Ordovician, and Silurian, while in the area immediately adjacent to the north and east pre-Cambrian rocks occur (see Pl. II). The Ordovician rocks are the ones which are most important from the present point of view. The Cambrian and pre-Cambrian beds are not, ore bearing and are not known to have had any direct influence upon the formation of the ores. The Silurian beds overlap the Ordovician and limit the field to the south and west, but are not otherwise related to the ores.

a Geol. Survey Illinois, vol. 1, 1866, pp. 153-207.

$b$ Geol. Survey Illinois, vol. 5, 1873, pp. 1-74.

$c$ For summary with citation, see Grant, U. S., Preliminary report on the lead and zinc deposits of southwestern Wisconsin: Geol. Nat. Hist. Survey ${ }^{\top}$ Wisconsin, Bull. No. 9, 1903, 103 pp. Also, Calvin and Bain, Geology Dubuque County: Geol. Survey Iowa, vol. 10, 1900, pp. 385-65\%. 


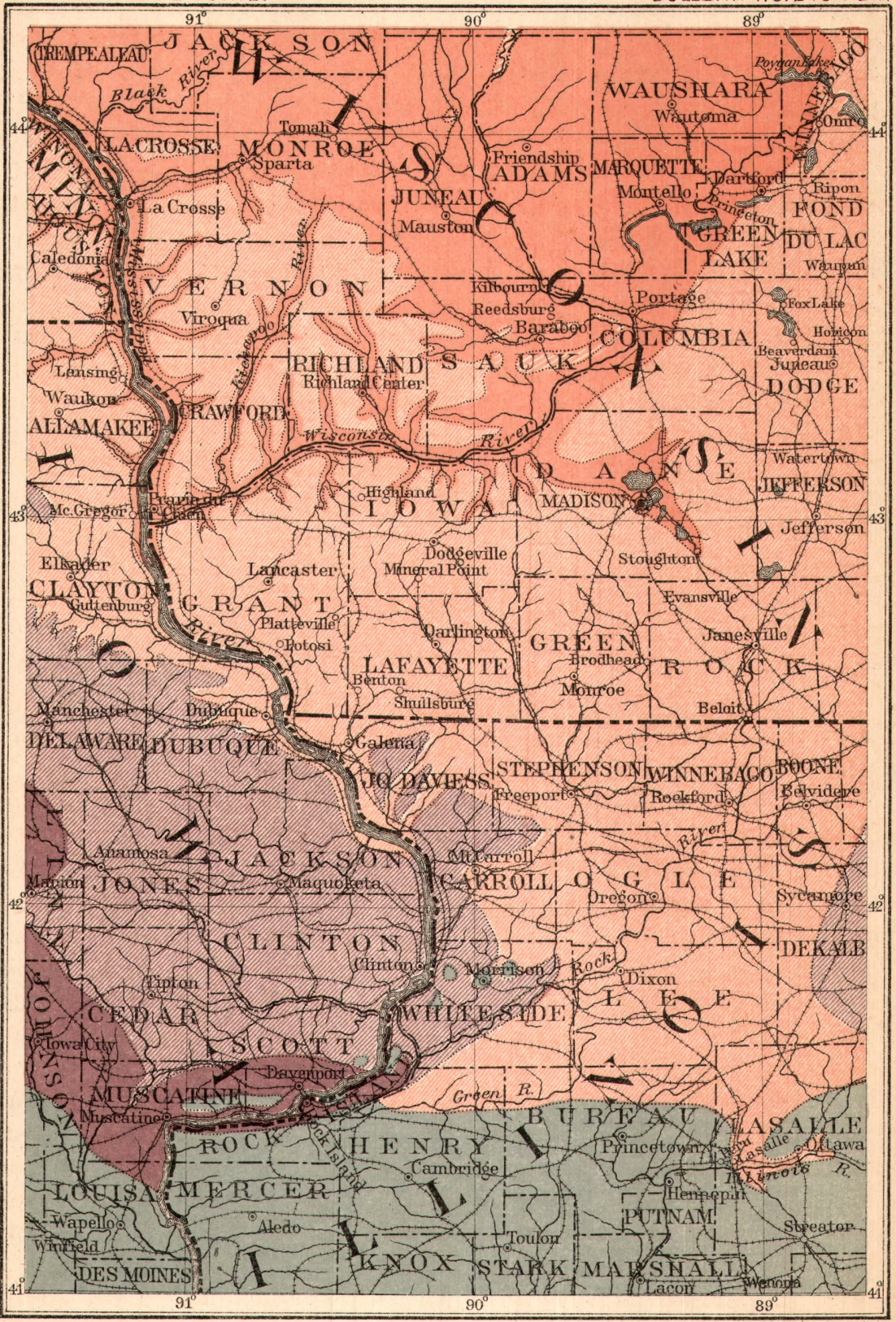

GENERAL GEOLOGIC MAP OF THE UPPER MISSISSIPPI REGION

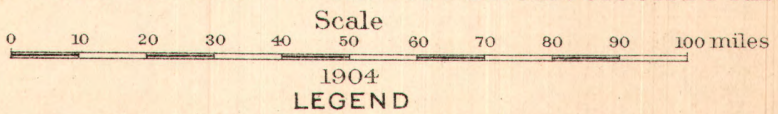

Carboniferous
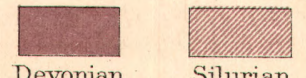

Ordovicion
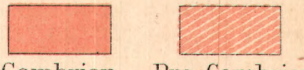

Pre-Cambrian 

A general section of the rocks present may be tabulated as below: GENERAL SECTION.

Section of rocks in northwestern Illinois.

\begin{tabular}{|c|c|c|c|}
\hline System. & Formation. & Character. & $\begin{array}{l}\text { Thick- } \\
\text { ness in } \\
\text { feet. }\end{array}$ \\
\hline Quaternary. & & $\begin{array}{l}\text { Alluvium. } \\
\text { Terrace deposits. } \\
\text { Loess. } \\
\text { Residual clays. }\end{array}$ & $10-70$ \\
\hline Silurian. & " Niagara." & Dolomite. & $150+$ \\
\hline Ordovician. & $\begin{array}{l}\text { Maquoketa. } \\
\text { Galena. } \\
\text { Platteville. } \\
\text { St. Peter. } \\
\text { Shakopee. } \\
\text { New Richmond. } \\
\text { Oneota. }\end{array}$ & $\begin{array}{l}\text { Shales. } \\
\text { Dolomite. } \\
\text { Limestone and dolomite. } \\
\text { Sandstone. } \\
\text { Dolomite. } \\
\text { Sandstone. } \\
\text { Dolomite. }\end{array}$ & $\begin{array}{r}175 \\
240 \\
60 \\
100 \\
50 \\
80 \\
200\end{array}$ \\
\hline Cambrian. & & $\begin{array}{l}\text { Sandstone, with minor shale and } \\
\text { dolomite. }\end{array}$ & 1,000 \\
\hline Pre-Cambrian. & & $\begin{array}{l}\text { Quartzite, with various igneous } \\
\text { rocks. }\end{array}$ & \\
\hline
\end{tabular}

PRE-CAMBRIAN ROCKS.

Rocks older than the Cambrian do not outerop at any point in the lead and zine district, though they are known to underlie the entire area. They have been encountered in deep wells at Lansing and other points, and outerop at many points to the north and east. The quartzite at Baraboo and the eorhyolites of central Wisconsin belong to this group.

The pre-Cambrian forms a floor, sloping gently to the southwest, upon which the later sediments rest. It lies 750 to 1,000 feet below the surface within the district, and is separated from the lowest Paleozoic beds by a pronounced unconformity, indicative of a long period of erosion.

\section{CAMBRIAN ROCKS.}

The Cambrian is represented in the district by a thousand feet or more of sandstone, with minor portions of shale and dolomite. The beds have been commonly referred to the Potsdam, though in the later Minnesota and Iowa reports they are given a local name, St.

Bull. 246-04-2 
Croix. At many points the beds are divided into an upper and a lower sandstone, between which occur dolomites or shales. So far these divisions have not been mapped throughout the field, and it is possible that they are not everywhere equivalent.

\section{ORDOVICIAN ROCKS.}

Oneota dolomite. - The basal member of the Ordovician is a massive dolomite 200 to 225 feet thick, to which McGee in 1891 gave the name Oneota ${ }^{a}$ as a substitute for "main body of the limestone," a term used some years earlier by Irving $^{b}$ to discriminate the lower portion of the "Lower Magnesian limestone" of Owen. ${ }^{c}$ McGee considered the Oneota to be the equivalent of the whole of the Lower Magnesian, and grouped with the St. Peter the overlying sandstone (New Richmond) ancl the thinner dolomite (Shakopee). Calvin ${ }^{d}$ has used Oneota to cover the whole group, discriminating the "main body of the limestone" under the title of lower Oneota. In order to avoid using upper and lower in a titular sense, it seems.well to go back to McGee's definition, so far as restricting Oneota to the lower or main dolomite is concerned, and to adopt the Minnesota terms, New Richmond and Shakopee, for the upper beds. In the earlier work in this portion of Wisconsin the three beds were mapped together under the old name Lower Magnesian limestone.

New Richmond sandstone.-This sandstone varies from 15 to 130 feet in thickness. ${ }^{e}$ It is not always well defined in outcrops, though W. H. Norton $f$ found it in deep wells as far south and west as Des Moines.

Shakopee dolomite.-As explained above, this formation is the equivalent of the upper Oneota of the Iowa Survey. It is a massive dolomite, approximately 50 feet thick, and is clearly defined in well records far south and west of the area of outerop, though not well exposed within the lead and zine district proper.

St. Peter sandstone.-This is one of the best known formations in the region. It is a clear saccharoidal sandstone, usually but slightly consolidated, and consisting of clean rounded grains of sand. The formation has a normal thickness of about 100 feet, though often much thinner. Neither the St. Peter nor the beds below it outcrop in the Galena district, though they come to the surface in adjacent portions of Iowa and Wisconsin.

Platteville limestone. - The beds included under this name have long been known in this district as the Trenton limestone. Since it is now believed that they are not the exact equivalents of the Trenton

$a$ Eleventh Ann. Rept. U. S. Geol. Survey, pt. 1, p. 332.

$b$ Am. Jour. Sci., 3d ser., vol. 9, 1875, p. 442.

$c$ H. Ex. Doc. 239, 26th Cong., 1st sess., 1840, p. 17.

dGeol. Survey Iowa, vol. 4, 1895, pp. 61-68.

e Norton, W. H., Geol. Survey Iowa, vol. 3, 1895, p. 183.

fGeol. Survey Iowa, vol. 6, 1897, pp. 115-428. 


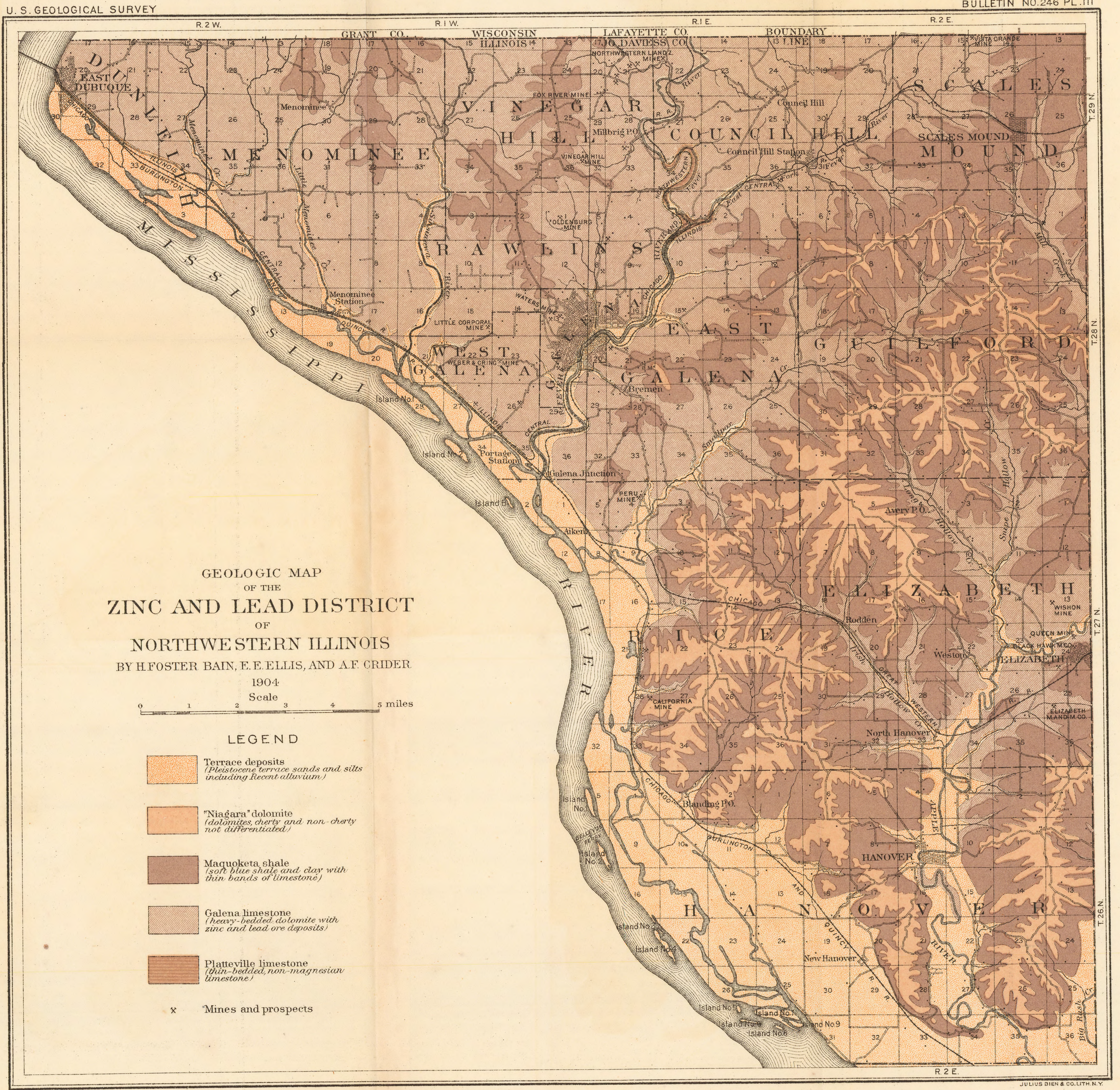


in its type locality, it is proposed to use a local name for them. The formation is typically exposed in the vicinity of Platteville, Wis., and its entire thickness may be seen along Little Platte River west of that town. The beds are largely made up of nonmagnesian limestone. In the lower portion are certain magnesian beds which are distinguished from the dolomites of the Galena by their earthy appearance. The Platteville limestone ordinarily has a total thickness of 60 feet, while extremes in thickness run from 40 to nearly 75 feet.

A generalized section of the Platteville includes the following beds:

Generalized section of the Platteville limestone in the upper Mississippi zinc district in Illinois.

4. Thin beds of limestone and shale.

Feet.

3. Thin-bedded brittle limestone, breaking with a conchoidal fracture _.. 25-30

2. Buff to blue magnesian limestone, heavy bedded, frequently a dolomite- 20-25

1. Shale, blue.

$1-5$

No. 1 of this section forms the base, and rests directly on the St. Peter sandstone; in fact, it rapidly grades downward into sandstone and at times is sandy throughout, though most commonly there is a distinct bed of shale free from sand grains of noticeable size. It is nowhere of great thickness, and while it is provisionally referred to the Platteville, it is possible that careful paleontologic studies may show that it belongs properly with the St. Peter or to a formation which, as developed elsewhere, lies between it and the Platteville.

No. 2 of the above section is the so-called buff limestone, or quarry rock, so far as it is developed in this particular region. It is always magnesian and is usually a dolomite. It is buff on weathered surfaces, but blue in fresh blocks. Its beds are from 6 inches to 2 feet in thickness, and it is thus markedly different from the rest of the Platteville. It holds its peculiar lithologic characteristics over large parts of the Upper Mississippi Valley even outside the lead and zine district. It is nowhere exposed in the Galena subdistrict.

No. 3 is frequently called the blue limestone and at times has been called "glass rock." It is a dense, very fine-grained limestone, which is commonly blue when fresh, but weathers to a white or light gray. The fracture is frequently conchoidal. The beds are thin, usually measuring from 1 to 2 inches, and, as they vary rapidly in thickness, the rock appears to be in gently undulating layers. Commonly there are very thin shaly partings between the different layers. Toward the east these beds become magnesian and form the "lower blue" of the Wisconsin section.

' No. 4 of the above section consists of limestone and shale. These are commonly in thin alternating beds, but there is comparatively little uniformity in this member in different parts of the district. In general it can be stated that the shale layers are better developed toward the west, while the limestone is the main part or the whole of 
the member in the eastern portion of the lead and zinc district. The shale beds are usually green or blue in color, though some of the beds are at times yellow, chosolate colored, or even black. The green shales are especially developed in Iowa. The chocolate-colored and black shales are highly carbonaceous, and are locally termed "oil rock," though the main bed of ehocolate-colored shale, or the "oil rock" of the lead and zinc district, lies just at the base of the Galena. The limestone is commonly a thin-bedded, fine-grained, blue rock, rich in fossils. At times it is subcrystalline, and, while usually nonmagnesian, becomes markedly magnesian toward the east, where it seems to be the equivalent of the "upper buff" of the Wisconsin section. The most marked beds of No. 4 in the type locality of the Platteville occur near the base of this member, and are termed "glass rock." These are the typical glass-rock beds of the lead and zinc district. They consist of dense, very fine-grained, hard, conchoidally breaking limestone, which rings when struck with a hammer. This glass rock is of a light-chocolate color when fresh, but weathers quickly to a light gray.

As a rule the Platteville is fossiliferous; markedly so in localities. This is especially true of Nos. 3 and 4 of the generalized section here given, but No. 2 is usually poor in fossils. The following brachiopods are common and characteristic of this formation: Leperditia fabulites Conrad, Orthis deflecta Conrad, Orthis tricenaria Conrad, Orthis perveta Conrad. The first two are, as far as at present known, confined to this formation; the others do not go below the Platteville, but extend in small numbers into the lower part of the Galena. A large variety of Orthis perveta Conrad is very abundant in No. 4 of the above section.

The upper part of the Platteville (No. 4) is the only part exposed in the Northwestern Illinois district. At East Dubuque and north of Galena, near the junction of the two branches of the Galena River, are small areas of No. 4.

Galena limestone.-Above the Platteville limestone, in the mining district, is a thick massive dolomite, which forms the main orebearing rock of the district. It has long been known as the Galena limestone, a name applied by James Hall ${ }^{a}$ to the beds in and around Galena, Ill., and above the so-called Trenton. The exposures around that place are accordingly typical for the formation, and show it to be made up of a granular, highly erystalline dolomite of dark-buff color. Owing to the predominance of solution over disintegration, it presents on weathered surfaces a very characteristic carious surface, marked by small pits and rounded protuberances (see Pl. IV). In hand specimens it often shows small open cavities of very irregular shape. These are often lined with dolomite crystals. When the rock weathers it breaks down into a coarse red sand, made up of individual crystals and crystalline particles of dolomite. 


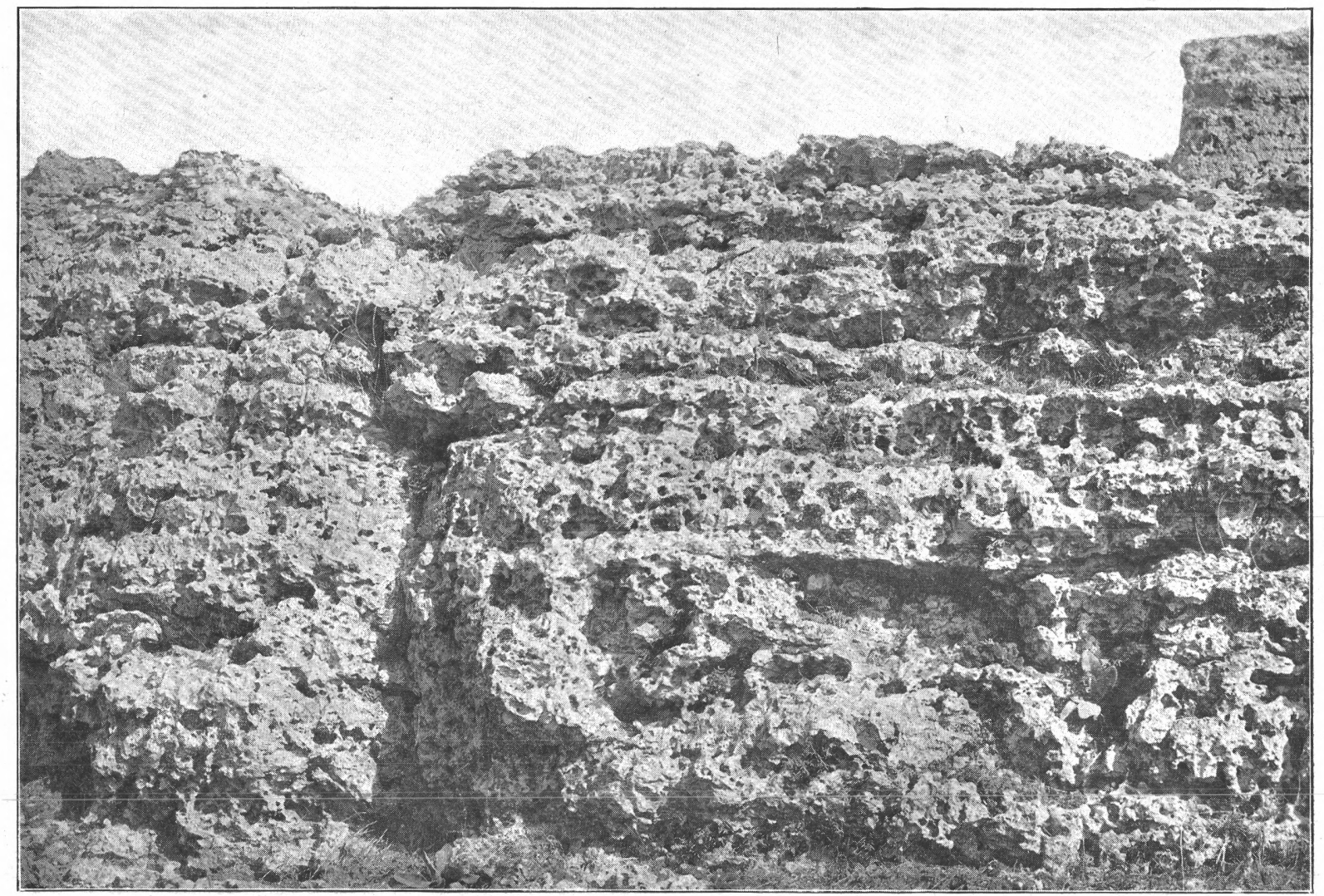

WEATHERED SURFACE OF GALENA LIMESTONE NEAR ROCKDALE, IOWA 

The formation is not very fossiliferous in its typical development. There are certain horizons, however, which are marked by particular fossils, and since these horizons maintain fairly constant relations to the top and bottom of the formation, they are of great service in working out the stratigraphy. Notable among these are two horizons, marked by Receptaculites oweni, known locally as the sunflower fossil, found rather constantly 70 and 200 feet below the top of the formation.

Chert or flint is abundant in the median portion of the Galena, usually occurring through a thickness of about 100 feet. The cherty beds and those above are exposed within the limits of the eity of Galena. The highest beds form the surface rock northwest of the town as far as the old tollgate. The lower beds come to the surface between that point and the junction of the two branches of Galena River. The formation has a total thickness of 240 feet, and its base at Galena lies about 534 feet above sea level. A somewhat generalized section of the formation is given below.

\section{Generalized section of the Galena limestone, Illinois.}

5. Dolomite, earthy, thin bedded

Feet.

4. Dolomite, coarsely crystalline, massive to thick bedded 60

3. Dolomite, thick to thin bedded, coarsely crystalline, chert bearing . . . . . $\quad 90$

2. Dolomite, thick bedded, coarsely crystalline .................... 60

1. Thin bedded limestone with shaly partings which are highly fossiliferous and, in part, at least, carbonaceous - the "oil rock" of the miners.

The basal member of the Galena, No. 1 of the above section, is well known throughout the zine district. It receives its name from the large amount of carbonaceous material which it contains, often sufficient to cause it to burn when lighted with a match. In the mining district it is everywhere recognized as the oil rock; ${ }^{a}$ and as there are usually several bands of shale interbedded with thin-bedded brittle limestone, the most important band is there discriminated as the main oil rock. Away from the mining district the horizon is occupied by a soft green clay. Usually the shaly element is most important at the top, and ordinarily-in southwestern Wisconsin, at least-a particularly bituminous parting is recognized as belonging to the oil rock.

North of the mining district the lower portion of the Galena is not dolomitized and is lithologically similar to the underlying Platteville. Since the lithologic character has usually been relied on in discriminating the two, the line between them has been drawn at different horizons in various parts of the region and from north to south has crossed the stratigraphic horizons diagonally. ${ }^{b}$

Maquoketa shale.-Above the Galena is about 175 to 200 feet of soft, blue to green shale, with occasional thin bands of limestone. This formation was entirely overlooked by Owen and the earlier investigators, but was recognized by Hall and correlated with the 
"Hudson River shale" of New York. ${ }^{a}$ There has been a great deal of discussion concerning the formation, ${ }^{b}$ but for present purposes it is sufficient to adopt and use the name proposed by C. A. White ${ }^{c}$ for the beds as developed in the adjacent portion of Iowa.

In Illinois the shale forms the lower portion of the slope of the Niagara escarpment, and also spreads out in a thin sheet over the higher portions of the upland plain already defined. The base of the shale forms a good datum plane from which the position of mine workings in the Galena limestone may be determined. It is usually marked by the presence of numerous small calcareous and phosphatic pebbles or pellets, one-fourth to one-half inch in diameter, and a number of fossils, of which the most common are a small Orthoceras and a small lamellibranch, Cleidophorus neglectus. With these are Liospira micula, Pleurotomaria depauperata, Hyolithes parviusculus, and Ctenodonta fecunda, as determined by Prof. Samuel Calvin.

The shales are rarely well exposed, but may be found in gullies cutting the sides of any of the mounds. They may be seen near the California mine, where one shaft went through nearly the entire thickness, and are excellently shown at the west front of the Chicago Great Western Railway tunnel in Rice Township, where the entire thickness is exposed.

\section{SILURIAN ROCKS.}

"Niagara" dolomite.-Above the soft shale of the Maquoketa is a body of fine-grained dolomite, carrying more or less chert. This forms the uppermost member of the stratigraphic section in this area. The beds in the lead and zine district form only the lower portion of the great thickness of strata which have long been known collectively as the "Niagara." There is no established local name for these particular beds, and since they were doubtless formed at some time within the "Niagara" epoch the group term will be provisionally used for them. The beds cap the mounds and the high escarpment which hems in the territory to the southeast. A thickness of 150 feet is present. The corresponding beds have been studied in some detail in Dubuque County, Iowa, and there the following section has been made out:

Generalized section of the "Niagara" formation, Dubuque County, Iowa.d

7. Upper quarisy beds

6. Cerionites beds

5. Pentamerus beds $\ldots \ldots \ldots \ldots$

4. Syringopora beds _...

3. Chert-bearing beds ... $\ldots \ldots \ldots \ldots$

2. Lower quarry beds . . . .

1. Basal beds

Total $\ldots \ldots \ldots \ldots$

a Foster and Whitney, Geology Lake Superior Land District, 1851, pt. 2, pp. 148-151. $b$ For summary and citations see Calvin, Geol. Survey Iowa, vol. 10, 1900, pp. 431-432. o Rept. Geol. Survey Iowa, 1870, vol. 1, pp. 180-182.

dGeol. Survey Iowa, vol. 10, 1900, p. 459 . 
In that portion of Illinois which has been studied Nos. 1 to 5 , inclusive, of the above section occur. The higher beds have apparently been removed by erosion. The chert-bearing beds are usually the most conspicuous, and fragments from them have so covered the lower quarry beds and the thick strata of the basal member that these are rarely seen.

The "Niagara" dolomite is distinguished from that of the Galena not only by the occurrence of certain characteristic fossils, of which Halysites catenulatus is probably most widespread and easily recognized, but also by fairly constant lithologic differences. In general, the "Niagara" is much lighter colored, finer textured, and is relatively free from the small irregular cavities which mark the Galena. It is not an ore-bearing rock, and apparently has little significance or importance in connection with the ore bodies.

\section{QUATERNARY DEPOSITS.}

The Quaternary deposits of the area have been treated in some detail by Chamberlin and Salisbury, ${ }^{a}$ Calvin and Bain, ${ }^{b}$ and Grant, ${ }^{c}$ so that only a few words are necessary at this time.

The deposits include residual clays, which may represent the whole of Quaternary and possibly a portion of Tertiary time; loess, which in the main at least is of Pleistocene age and to be correlated with the Iowa drift sheet; terrace gravels and silts, which are of Pleistocene age and so far as definitely fixed belong with the Wisconsin drift; and alluvium, which is post-Pleistocene, or Recent, in age.

Residual clays. - The deep-red sticky clay containing small pieces of chert and limestone, which may be noticed at many points below the loess, represents the residuum from the decay of the limestones and dolomites. Grant has ealculated ${ }^{d}$ that 3 feet of this material represent 100 feet of preexisting limestone, and it is accordingly an impressive token of the large amount of erosion which the region has undergone, even though it is nowhere very thick.

Loess.-The light-buff earthy clay which forms a thin mantle extending from the Mississippi eastward represents the loess. It has not been restudied in any detail, but there are no known reasons for doubting that it forms a portion of the general loess sheet of this region. It is significant in that it mantles the hills and valleys in such fashion as to indicate clearly that, as compared with the erosion which took place in the area before it was laid down, almost none has occurred since. The dissection of the old peneplain by the present streams was almost wholly accomplished before the loess was deposited.

$a$ The driftless area of the upper Mississippi: Sixth Ann. Rept. U. S. Geol. Survey, 1885, pp. 239-311.

b Geol. Dubuque County: Geol. Survey Iowa, vol. 10, 1900, pp. 459-475.

c Op. cit , pp.14-19.

dOp. cit., p. 18. 
Terrace deposits.-Along the Mississippi there is a well-defined terrace, underlain by gravels and sands of glacial derivation. It may be traced up the river and certain of its branches to a connection with the Wisconsin drift sheet, and for that reason has been considered to be of Wisconsin age. It is possible that older terraces, representing earlier stages of the ice, are confused with it.

Within the Galena subdistrict the streams tributary to the Mississippi have their sources wholly within the driftless area. The terrace occurring along them is accordingly underlain with material of local origin, laid down in quiet ponded waters at the time when the main terrace was formed in the Mississippi Valley. This material is a fine silt or clay, closely laminated. It is shown in the city of Galena at many points, Grant Park being located on the top of the terrace. (See fig. 1.) The general distribution of the terrace material is shown on

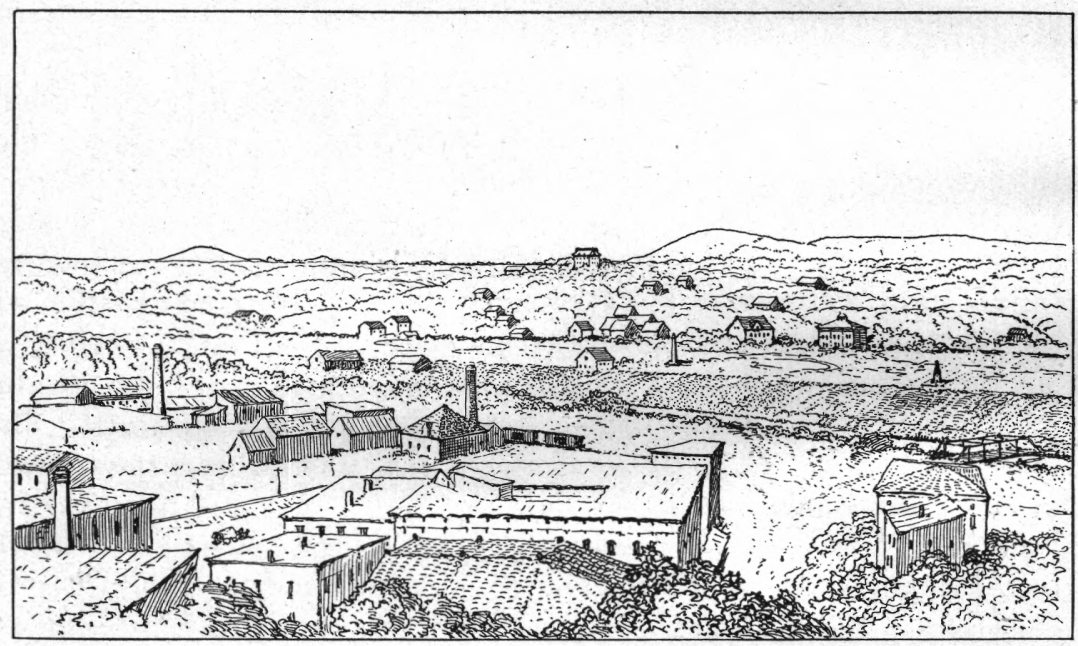

FIG. 1.-The mounds, upland, and river terrace, as seen from Galena, Ill., looking southeast.

the accompanying map, Pl. III. For convenience, the modern alluvium within the terrace limits is mapped with the latter.

Alluvium.-The streams are now depositing in time of floods as in the past, and irregular stretches of bottom land are found along them from their mouths well toward their sources. No attempt has been made to represent these areas on the map. In general they are irregular, and the streams have rock bottoms. Near Hanover, as is shown on the map, the Galena dolomite occurs in the bottom of Apple River for nearly 2 miles below the point at which the dip carries it below the terrace. At Galena, on the other hand, Galena River, like the Mississippi, is running over a filling of Quaternary age. Opposite East Dubuque the rock bottom of the Mississippi occurs at 405 to 452 feet above sea level, ${ }^{a}$ a fact that has been frequently interpreted as indicating a pre-Glacial or inter-Glacial elevation of the area. If this 
be the correct interpretation, the period of higher elevation was too short to influence the tributary streams any considerable distance from their mouth.

In view of the large importance of seour, to which J. E. Todd has called attention, ${ }^{a}$ and the evidently large volume of the Mississippi at certain times during the Pleistocene, it is possible that the depth of the valley is not a measure of an earlier elevation of the land.

\section{GEOLOGIC STRUCTURE.}

The rocks in this area have a gentle dip to the south and west, amounting only to 1 or 2 feet to the mile. In the region are a few low folds, but none have been found in the Galena subdistrict. To all appearances the rocks are quite undisturbed. There is no faulting, and, except for the very important joint planes, the rocks are unbroken.

\section{GEOLOGIC HISTORY.}

The strata occurring in this area record a number of long periods of sedimentation. These included portions at least of Cambrian, Ordovician, and Silurian time. The history of the district in preCambrian time is not very definitely known, and it can only be said that at some time in it the area became land and remained above the sea for a very long time before the first sediments of the Cambrian were laid down over it. At some time in the Cambrian, probably in the middle, this land sank beneath the ocean waters and sedimentation began. Except during certain intervals not well recognized, the sea then retained possession of the area until the close of the "Niagara " epoch and possibly longer. It is probable that at different times parts at least of the area were lifted above the sea and deposition temporarily ceased. Of these intervals of nondeposition, the most significant from the present point of view is that which is supposed to have followed the deposition of the Galena dolomite. The evidence of this interval is not strong, but in the frequent presence at this horizon of pellets or pebbles of limestone, in the marked change in the character of the sedimentation, and in the considerable faunal break are found reasons for believing in at least some rearrangement of the ocean border.

The Galena limestone as developed in its typical area is a simple massive dolomite, with only the thinnest of shale partings between its thick beds. To the north the equivalent strata become largely nonmagnesian limestones, separated by thicker shale partings. The change in character occurs at higher and higher horizons as the distance to the northwest increases. These conditions have been noted in both Iowa ${ }^{b}$ and Minnesota, ${ }^{c}$ and have been interpreted as indicat-

$a$ Bull. U. S. Geol. Survey No. 158, 1899, pp. 150-153.

$b$ Norton, W. H., Geol. Survey Iowa, vol. 6, 1897, p. 146; Calvin and Bain, Geol. Survey Iowa, vol. 10, 1900, pp. 403-411.

c Winchell, N. H., Amer. Geologist, vol. 15, 1895, p. 33. 
ing that the dolomite of the Galena was deposited in a semiinclosed offshore basin to which the sediments represented in the shaly partings of the nondolomitic phase did not penetrate and in which evaporation was unusually active. In this shallow basin organie remains slowly accumulated, and as fast as formed were altered by the action of the magnesia in the overlying sea water. Eventually the basin may have become entirely filled or cut off from connection with the ocean and the whole of the remaining water evaporated. On the other hand, the basin may have only become very shallow before the influx of muddy water from which were deposited the lowest beds of the Maquoketa. With that incursion the dominance of the sea was reestablished.

Whether this area was ever covered by the sea after the "Niagara" epoch is not certain. There are in the adjacent regions small outliers which have been found to be of Devonian, Carboniferous, Cretaceous, and possibly Tertiary age, and it is not impossible that beds representing some of these periods may have once covered the driftless area. The next period, however, of which we have definite record, was one of erosion, as is made evident by the peneplain already described as occupying much of the district. This plain, which euts across soft Maquoketa shale and hard Galena dolomite alike, marks a time during which the land was stable sufficiently long for the streams to reduce to a fairly even plain all the territory from the mounds far to the north.

The age of this peneplain is not definitely fixed, but there are reasons for believing that it represents the closing stage of the Tertiary. The epoch in which it was formed was terminated by an uplift, accompanied by a tilting to the south, and the wide meandering streams began to cut their channels down into the peneplain. They are still engaged in this task, and, so far as the evidence of this immediate territory shows, the work has been uninterrupted. At times during the occupation of the surrounding region by ice, the Mississippi carried an unusual amount of water, which caused it to widen its valley and to truncate the salients between the tributary streams. With the return of normal conditions of volume it was unable to carry the material with which it was loaded, and so built the terrace upon which parts of Dubuque and many other river towns are built. At the same time, in the ponded lower portions of the tributary streams, silts were deposited to an equivalent level. The upper portions of the streams were unaffected, and to all appearances nothing has disturbed them since the uplift of the peneplain. If, during Pleistocene time, there were elevations and depressions of the area, they were so slight or of such short duration as to leave no mark on the courses of the streams. 


\section{ORE DEPOSITS.}

THE ORES.

\section{MINERALS OF THE ORES.}

The minerals which enter into the composition of the ores, or which are associated with them, have been described in some detail by Chamberlin. ${ }^{a}$ Interesting additional information has been given by Leonard, ${ }^{b}$ and a special erystallographic study has been made by Hobbs. ${ }^{c}$ At this place only the more important minerals present will be listed and their general character noted.

Galena.-(PbS; lead 86.6 per cent, sulphur 13.4 per cent, specific gravity 7.4 to 7.6.) This is the only lead mineral found in any quantity in the region. It occurs usually in well-defined cubes joined together into aggregates of greater or less size. The galena is known locally as "mineral," and was the basis of the early mining industry of the district. In contrast with galena in general it is not argentiferous $^{d}$ to any appreciable degree.

Cerussite.- $\left(\mathrm{PbCO}_{3}\right.$. $)$ This mineral occurs as a white coating over galena crystals and is doubtless an alteration product. It is now seldom noted, though formerly, when more galena was being mined, it was frequently found.

Sphalerite.-(ZnS; zine 67.15 per cent, sulphur 32.85 per cent, speeific gravity 3.9 to 4.1.) This is rapidly becoming the most important ore mineral in the district. It is commonly known as "jack," or zine blende, and occurs as sheets and irregular aggregates of imperfectly developed crystals. It is dark in color and contains a small amount of iron apparently combined with the zinc and sulphur.

Smithsonite.- $\left(\mathrm{ZnCO}_{3}\right.$; zinc oxide 64.8 per cent, carbon dioxide 35.2 per cent, specific gravity 4 to 4.45 .) Next to blende this is the most important mineral in the district; for many years it was almost the only one mined. Smithsonite is known locally as "carbonate" or "drybone," and occurs in two general forms. The first is a clear lustrous mineral, often forming sheets, lining small cavities, and not infrequently making up stalactites and pseudomorphs, especially after calcite. The second form is the common one, and is that in which the mineral is usually shipped. It is earthy in appearance and varies from a high-grade cellular rock, for which drybone is an apt name, to lower grades hardly to be distinguished in appearance from the iron-stained dolomite of the region.

Pyrite and marcasite.- $\left(\mathrm{FeS}_{2}\right.$; iron 46.7 per cent, sulphur 53.3 per

$a$ Chamberlin, T. C., Geol. Wisconsin, vol. 4, 1882, pp. 380-398.

$b$ Leonard, A. G., Geol. Survey Iowa, vol. 6, 1897, pp. 9-65.

$c$ Hobbs, W. H., Bull. Univ. Wisconsin, Sci. ser., vol. 1, No. 4, 1895, pp. 109-156; Zeitschr. für Kryst., vol. 25, 1895, pp. 257-275.

$d$ Chamberlin, op. cit., p. 382. 
cent, specific gravity 4.67 to 5.2.) These minerals are everywhere intimately associated with the blende and frequently with the galena. The marcasite is the more common and occurs as sheets and botryoidal aggregates of thin tabular crystals. The two minerals are not usually distinguished and are known locally as "sulphur."

Limonite and hematite.-Both the hydrous and anhydrous oxides of iron occur in the region, and limonite in the form of ocher is very commonly associated with the zinc-carbonate ores.

Chalcopyrite.- $\left(\mathrm{CuFeS}_{2}\right.$.) No chalcopyrite has been observed in the Galena subdistrict, though it is probably present in small quantity. It is known to occur in the Wisconsin mines.

Malachite and azurite.-These brilliant-colored alteration products of the chalcopyrite are frequently found in the district, though in insignificant quantity.

Barite.- $\left(\mathrm{BaSO}_{4} \cdot\right)$ This mineral has occasionally been found in small quantity in various parts of the district, and it is reported from Scales Mound, in Illinois. It is nowhere conspicuous and has no economic importance.

Gypsum.- $\left(\mathrm{CaSO}_{4}+2 \mathrm{H}_{2}\right.$ O. $)$ Sinall erystals of gypsum have frequently been found in the district and have occasionally been mistaken for anglesite, the lead sulphate. They are of some importance in the light which they throw upon the probable reactions which took place in the genesis of the ores.

Calcite.- $\left(\mathrm{CaCO}_{3}.\right)$ In the form of limestone calcite is one of the most common minerals of the district. It also occurs erystallized and in erystal aggregates in druses and open cavities in the ores. Both calcite and the orthorhombic form of calcium carbonate occur in a wide variety of beautiful forms in the caves of the region. Some of these forms have been described and illustrated by Leonard. ${ }^{a}$

Dolomite.- $\left(\mathrm{MgCaCO}_{3}\right)$ is even more common than calcite, but is very rarely found in the form of individual crystals, except as the latter make up the country rock. In this the ores are in sharp contrast with those of the Joplin district, where in an area of nonmagnesian limestone such dolomite as is present usually occurs in well-defined crystals.

Wad.-The amorphous black oxides of manganese are widely distributed in small quantity throughout the district. They occur usually in the form of a fine black powder resembling soot, and in some of the old lead workings they are fairly abundant. One of the crevices at Dubuque is called the "black crevice" from the abundance of this mineral. Some of this mineral has been determined to be pyrolusite $\left(\mathrm{MnO}_{2}\right)$, but probably other minerals also are present.

Less abundant minerals. - In addition to the minerals listed above, there are a number which are present occasionally in small quan- 
tity, such as melanterite (iron sulphate); and others, which, while present, are not of any apparent significance as regards the ore deposits, such as quartz, which in the form of sand and chert is widespread.

An interesting and significant fact is the entire absence of fluorite, which occurs in quantity in the Southern Illinois district, and of the complex compounds of antimony, arsenic, and silver, which are constant associates of lead and zinc minerals in the western States.

\section{PARAGENESIS.}

The association of the minerals with one another is interesting and instructive. Chamberlin devoted some time to a careful study of their order of deposition. ${ }^{a}$ Van Hise ${ }^{b}$ summarizes these observations as follows:

The full succession at various openings, from the wall to the druse, is (1) marcasite; (2) ferriferous sphalerite; (3) galena in cubic crystals; (4) ferriferous sphalerite, subordinate in quantity; (5) marcasite; (6) galena in octahedral crystals, very subordinate in quantity. Some of the elements of this succession are lacking at various veins. A very common order is (1) sphalerite, (2) galena, and (3) marcasite.

So far as present observations go the most common order is (1) marcasite, (2) blende, and (3) galena or marcasite, or both. The marcasite first deposited forms a thin sheet, not usually more than 1 millimeter in thickness, lining the solution cavities in the dolomite. It is rarely absent. The blende formed over it varies in thickness from a few millimeters to 3 or 4 inches. On the blende are scattered crystals of galena and marcasite. Grant calls attention to the fact that in the deeper mines the order very frequently is (1) marcasite, (2) galena and blende, and (3) blende.

Probably the more significant, however, is a grouping corresponding to the vertical order of succession of the dominant ore minerals. According to this grouping the ores may be classed as (1) galena or lead ores, (2) smithsonite or zinc-carbonate ores, (3) blende or zincsulphide ores.

Galena or lead ores.-These are the characteristic ores of the upper horizons and are the ores which attracted attention in the early history of the region. In them galena is the dominant mineral and all other minerals are very subordinate. These ores range in general from the surface down to the level of underground water, and much the largest quantity of mineral so far obtained has been found as loose masses in dolomite sand, which is residual from the decomposition of the country rock. Iron and manganese oxides are commonly found in these ores in small quantity, though sufficient to give a rusty brown or black color to the mass. Despite the many years of careful 
prospecting since the district was first opened, small quantities of these ores are still being found and mined. They formed the basis of the early mining of the region, and the working of them calls for only the simplest machinery and methods.

Smithsonite or zinc-carbonate ores. - Somewhat below the lead ores proper, beginning, however, above the actual level of underground water and extending a little below it, is the zone from which in the years 1860 to 1890 the main ores of the region were obtained. In this zone the amount of galena present is much less than in that above; the dominant mineral is zine carbonate. With it are minor amounts of galena and toward the bottom increasing amounts of zine sulphide and iron sulphide. The relations of the zine earbonate to the zine sulphide are in many cases such as to make it clear that the carbonate is an alteration product from the sulphide. ${ }^{a}$ The oxides of manganese and iron are present in this zone, as in that above. The ores carry from 20 to 40 per cent of metallic zine as usually prepared. They are mined and dressed ordinarily with only the simplest machiney.

Blende or zinc-sulphide ores.-Below the zone of zinc-carbonate ores is that in which blende becomes in turn dominant. It extends from near the level of underground water down to the "oil rock," and in one or two cases a short distance below. Associated with the blende are galena and the sulphides of iron. The latter occur in considerable quantity, and the various sulphides are so intimately mixed as to preclude any successful attempt at determining an invariable order of deposition. The order (1) iron sulphide, (2) blende, (3) minor amounts of galena, is common; the reverse order and various permutations of it also occur. Clear well-defined crystals of calcite frequently occur in this zone. The dominance of the blende and the intimate mingling of the sulphides, with the absence of alteration products, are apparently the significant features of this zone.

The zinc-sulphide ores are the ones now being worked at most mines. Their mining and dressing require usually the erection of much more elaborate plants than are necessary in the case of the other ores, and necessitate good pumping and milling equipment. This requires more capital and results in the concentration of effort upon a smaller number of veins. It is this stage of mining that is becoming more and more important in the district.

\section{MODE OF OCCURRENCE.}

FORM OF THE ORE BODIES.

CREVICES.

Definition.-The ores of the district occur in what have long been known locally as " crevices," and for which Whitney ${ }^{b}$ coined the term 
"gash vein." Gash veins he considered to be intermediate in character between segregated and true veins. They occupy preexisting fissures, but are of limited extent, being usually restricted to a particular formation and not being eonnected with any extensive movement of the rocky mass. As developed in this district, these veins occupy joint cracks. Usually, instead of a simple continuous fissure, there are a number of parallel fissures occupying en échelon positions. Collectively they are know as a "range."

Joints.-There are two systems of joints commonly developed in this area. The joints of the most prominent system cut across the beds normal to the stratification, and the best developed planes usually approximate an east-west direction. There are less perfectly developed planes running north-south. Quartering crevices appear at various angles between the two.

Joints of the second system eross the beds at an angle of $45^{\circ}$ to $60^{\circ}$ with the stratification planes. The best developed often strike with those of the vertical system, but there seems to be no direct relation between the two systems.

The erevices are developed along the vertical joint planes. The pitches and flats occupy the inclined joint planes and the bedding planes, respectively. The vertical joints, and hence the crevices, are best developed within the first hundred feet of the surface. The inclined joints obtain their best development below that depth.

Both sets of joints may be seen excellently developed in the bluff at the east end of the Dubuque bridge and are illustrated in Pl.V, $A$, from a photograph made at that point by Dr. U. S. Grant, of the Wisconsin Geological Survey. The fine lines running diagonally from right to left represent the inclined joints. The vertical joints are here more widely spaced and less regularly developed. The wide spacing is characteristic throughout the district, but the irregular development is not. In general, the vertical joints are notable for their extent and regularity. In the picture the bedding planes and chert bands are shown ị characteristic development.

It will be noted that, contrary to the ordinary rule, the inclined joints do not have in this view a second set developed at right angles to them. Such a set is, however, present in the area and is well displayed about 150 feet north of the spot shown in the photograph. So far as observation goes, these two sets are developed always in general proximity, but not in immediate juxtaposition. Between the two here, as in the mines, there are two or three well-defined vertical joints or crevices.

Openings,-The joint planes are simple eracks through the rock. They are not planes of any appreciable faulting, and though the vertical joints are very persistent, would not in themselves afford space for much ore. They have, however, been materially enlarged by the dissolving action of underground waters. Locally this action 
has been quite uniform along the plane, and space has been eut out in which a simple sheet of mineral from a quarter of an inch to as much as 4 inches in thickness has been deposited. This form of ore body seems to be especially characteristic of the crevices occupying north-south and quartering joints. Along the main crevices, which over most of the area are east-west, solution has been more active and irregular cavities and chambers have been excavated. There is a tendency for these to form at certain stratigraphic horizons, which differ from camp to camp, but are fairly constant within the limits of small areas. At the intersection of these planes and the joint planes the crevice either widens out abruptly and an open space is formed or the rock becomes soft and thoroughly disintegrated. In either case the term "opening" is applied.

The openings are usually from 1 to 4 feet wide and from 4 to 6 feet high. Occasionally the rock between two crevices has been eut out by solution and broad chambers 25 to 30 feet wide and 30 to 40 feet high may be formed. Such chambers may be 500 feet long, while

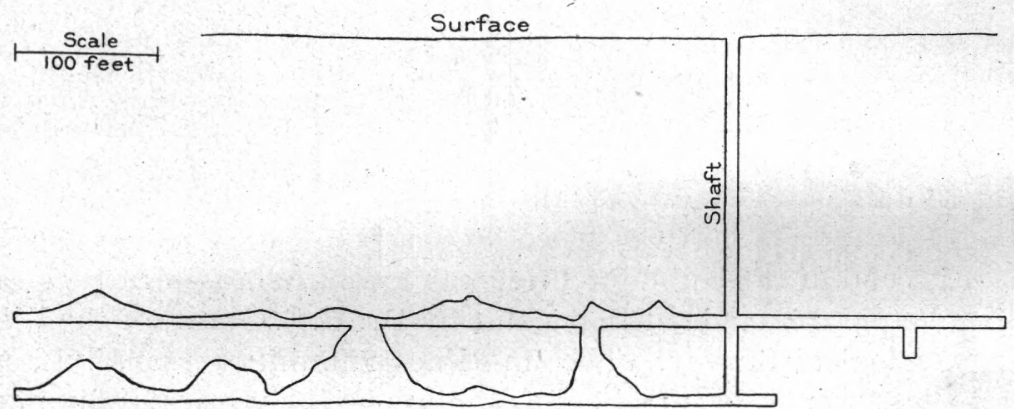

FIG. 2.-Vertical east-west section along the McNulty crevice, Avenue Top mine.

lengths of 1,000 feet are not uncommon for the smaller openings. In certain cases, as a result of this softening of the rock, by very little digging connections have been made so that a mile or more may be traveled underground along an individual erevice. The walls of the opening usually show firm dolomite not especially disintegrated. Frequently they exhibit a pitted surface very similar to that which the same dolomite takes on exposure to weathering agencies at the surface. The roof of the opening may either be a flat "cap rock" through which the crevice can be traced only by a line of water seepage, or be irregular as a result of the presence of "chimneys" which often extend as pipes from one opening to another. In many mines three distinct openings, one below another, are present. Two such openings are illustrated in PI. V, $B$, from a photograph taken in Dunleith or East Dubuque by U. S. Grant.

The combination of horizontal openings and vertical chimneys makes a system of ore bodies quite deceptive to those not acquainted with the peculiarities of the district. In fig. 2 , a plan in the vein, a 


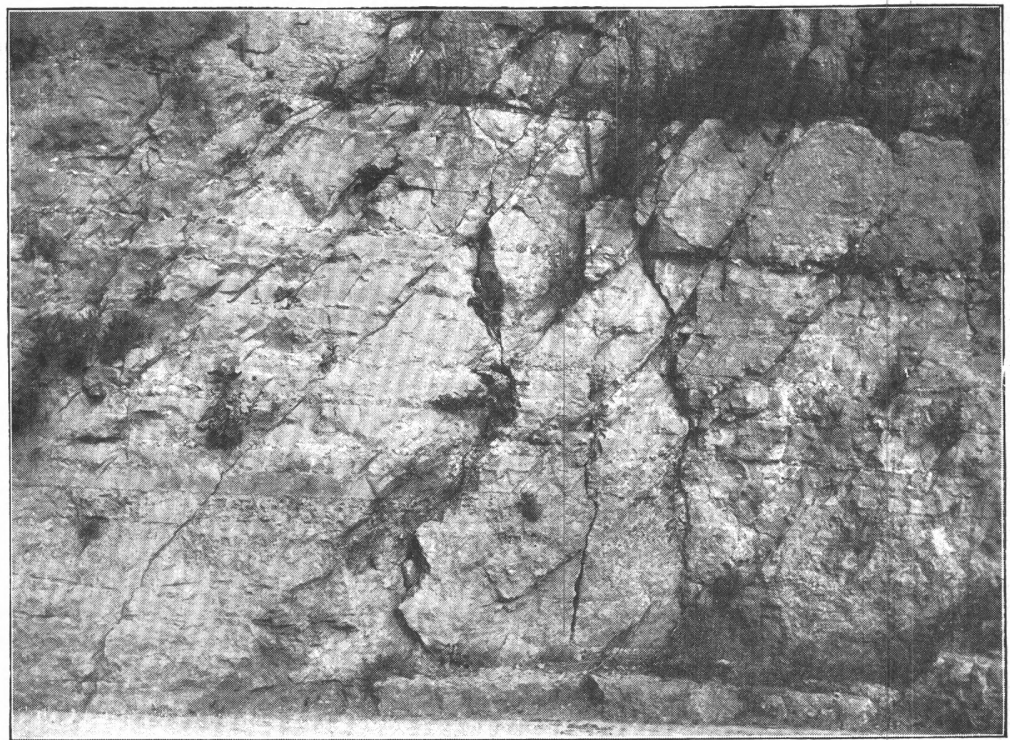

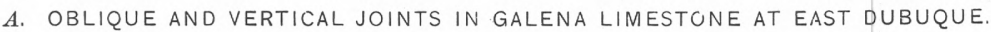

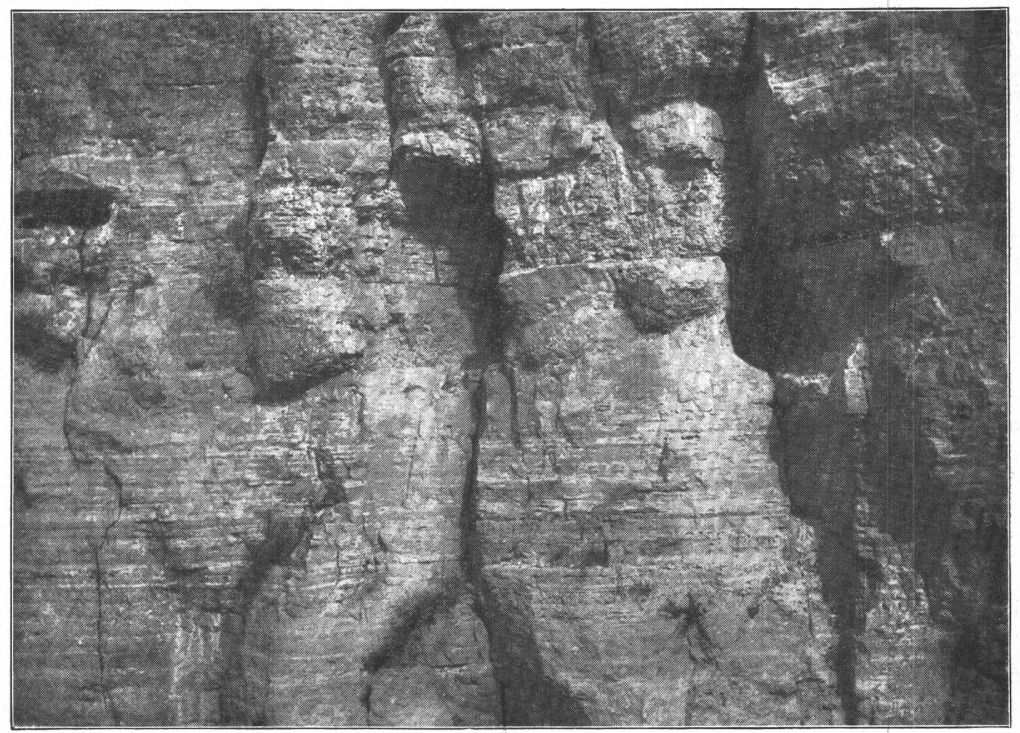

B. CREVICES AND OPENINGS IN GALENA LIMESTONE AT EAST DUBUQUE. 

portion of the Avenue Top workings at Dubuque is illustrated. At first glance there would seem to be a considerable amount of unstoped ore blocked out. As a matter of fact, only a thin coating of lean ore remains on the walls, and the blende which occurs at intervals along the bottom of the lower level is probably as patchy in distribution as the irregular worked-out stopes above the level show the "drybone" to have been. One of the chimneys, it will be noticed, lengthened into a small stope, and similar stopes 50 to 80 feet long are not unknown, though they are rare.

Ores of the crevices.-In the crevices and openings the characteristic ore is the galena. This occurs as (1) thin sheets completely filling the smaller crevices; (2) crystals and crystalline aggregates clustered on the walls; (3) fallen and broken masses in the loose dolomite sand mixed with broken pieces of rock. The sheets have yielded relatively little mineral. In 1839 Owen estimated ${ }^{a}$ that a regular sheet one-half inch thick could be worked profitably in solid rock that required blasting, while in loose ground a vein one-fourth of an inch thick would pay. Such thin sheets have not been worked for some years except in hope of their leading the prospector to a cave or pocket of mineral. It has been the open chambers which have yielded the great bulk of the lead ore. From 1,000 to 2,000 tons of clean galena have in a number of cases been taken from individual openings.

Not only the galena ore but the bulk of the zinc-carbonate ore has come from the crevices and openings. In these the smithsonite occurs as loose fragments mixed with the broken rock and sand, as incrustations lining the solution pits of the walls and covering the blocks of tumbled rock, and as a replacement of the dolomite. To a variable but never great extent the smithsonite metasomatically replaces the dolomite of the walls, forming a low-grade carbonate ore.

FLATS AND PITCHES.

Definition.-The most interesting and unique forms of ore bodies in the district are the flats and pitches. In these the ores follow in part the vertical joint planes, in part the bedding planes, and in part the dipping joint planes. The result is an ore body occurring in a series of horizontal sheets called "flats" connected by a series of dipping sheets or "pitches." These pitches are often parallel to the main vertical crevice and pitch outward from it on both sides. The ore spreads out along the bedding planes both toward the main vertical crevice and away from it. It also descends from bedding plane to bedding plane by a number of parallel pitches. The deposition of the ore in the cavities formed by the combination of joints and bedding usually has been accompanied by some metasomatic

Bull. 246-04-3 
replacement of the country rock, particularly that of the core between the two sets of pitches and the vertical crevice.

Illustration.-Since none of the mines now open in Illinois are working in the flats and pitches, those of the Empress mine near Benton, Wis., will be illustrated. The ground plan of this mine is shown in fig. 3 from detailed surveys by Messrs. Hancock and Fulcher, of the Wisconsin Geological and Natural History Survey. The main vertical crevice here has a magnetic bearing $\mathrm{N} .87^{\circ} \mathrm{E}$. It has been traced for some distance beyond the limits of the particular mine, as is shown by old shafts along its course. In the mine there are roughly parallel to it on the north and south outward-pitching crevices in which ore has been formed. The ground plan and the cross sections, all drawn to scale, illustrate better than can be done in words the relations of the ore bodies to the various crevices and bedding planes.

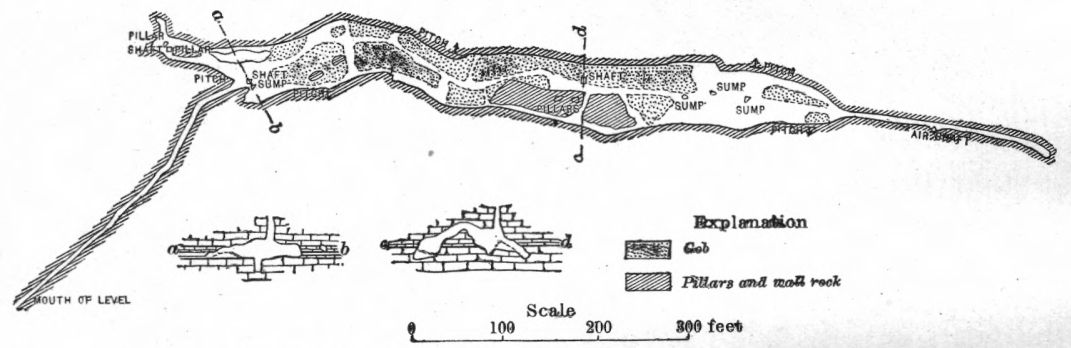

FIG. 3.-Plan and cross sections of the Empress mine.

Position.-The flats and pitches are best developed in the lower part of the Galena limestone. They reach their maximum size and importance in the beds between the flint and the top of the Platteville limestone. They occur, however, as high as the top of the flint beds and as low as the "glass rock" of the Platteville.

Ores of the flats and pitches. - The characteristic ore of the flats and pitches is the zinc-sulphide ore. It is in them that blende and its associated minerals are most commonly found, though this may be due to the fact that they are rarely developed above water level, as well as to their position low in the formation. Well-developed pitches were found above water level in the Stewart \& Bartlett mine at Dubuque, ${ }^{a}$ and yielded large quantities of galena ore.

The development of the flats and pitches seems to be dependent either upon the character of the beds, and hence related to their stratigraphic position, or upon the amount of cover, and hence determined by their topographic situation. At present there are no sufficient data for determining which of the two factors is the more important. The character of the ore which happens to fill them is determined, as noted above, by other conditions, mainly the position of the underground water level. 
Importance.-It is believed that the flats and pitches contain the important ore reserves of the region. The ore in the crevices and openings is in most instances small. Its distribution is irregular and uncertain. On the other hand, very little observation is required to convince one that the flats and pitches contain large amounts of ore of milling grade. The crevices are important as serving to mark out the ground within which it is wise to prospect for the lower-lying flats and pitches.

\section{RELATIONS OF THE ORE BODIES TO STRUCTURE.}

The attempt has frequently been made, though without notable success, to group the crevices so as to bring out structural relations. There are neither faults nor folds of any importance in this region. The structure, so far as it has been determined, is that of a simple monocline of very gentle slope. There are occasional interruptions of the dip, but these are slight and of doubtful significance. In some instances there seems to be a relation between the ore bodies and such folds as occur, but the relations are not clear, and the evidence is somewhat confusing. It is, however, hardly probable that joints of such persistence and regularity would be developed throughout so large an area except under the action of forces of great extent and significance. Additional study may throw light upon this phase of the subject. Such investigations are now being carried on in great detail by Dr. U. S. Grant, of the Wisconsin Geological and Natural History Survey, and pending the completion of his studies no definite statement can be made.

RELATIONS OF THE ORE BODIES TO TOPOGRAPHY.

It is a well-recognized rule that throughout the district the ores have been found on the slopes and in the minor valleys. There is, it is true, within the productive area very little actually flat ground, but nevertheless there is significance in the fact that the mines are located in every observed case some distance below such divides as are present. Very little mining has been done below actual bottom land, but this may be less significant as indicating only a disinclination on the part of the miners to attempt wet mining.

\section{RELATIONS OF THE ORES TO UNDERGROUND WATER LEVEL.}

The relations of the ores to the underground water level have already been suggested. The largest bodies are found within a short distance below this horizon. Normally the lead ores are above it, the zinc-carbonate ores are near it, and the blende lies below it. These zones of ore grade into one another, and, owing to the rough topography of the district, the water table is very irregular, so that all classes of ores may occur at the same stratigraphic horizon within short dis- 
tances of one another. Near the Mississippi it is often 100 to 150 feet to permanent water. In such cases the zinc-carbonate ore zone is ordinarily of unusual thickness. The thickness of the zone of blende ores seems to be determined by the distance between the level of underground water and the oil rock at the base of the Galena limestone. While it is by no means certain that where the water level is high in the rocks blende may be expected in large quantity down to the oil rock, such experience as is available favors this view.

\section{DESCRIPTION OF MINES AND PROSPECTS.}

\section{GENERAL STATEMENT.}

In the summer of 1903 there were in northern Illinois about fifteen places at which mining or prospecting was being carried on vigorously. A much larger number of old diggings were found in the district, and some of these, not improbably, are prospected more or less during the winter season. No attempt will be made here to systematically describe these old workings, but the following brief descriptions of the mines visited will illustrate what may now be learned about the district, and suggest something of what continued prospecting may be expected to show. The location of each of the mines is indicated on the accompanying map (Pl. III), together with that of numerous other prospects, some of which were being worked when visited, but most of which were idle. For the locations of the crev. ices, so far as they were known at the time when lead mining was most active, the reader is referred to Whitney's ${ }^{a}$ map accompanying his report to the State geologist of Illinois, and also to the map of the crevices in the entire district in his later report. ${ }^{b}$

The altitudes given in the following descriptions were all determined by aneroid, checked as carefully as possible upon railway levels. They should be regarded as approximate only.

\section{WATERS MINE.}

This mine is located on the hill and within the limits of the city of Galena. It was for some time under bond to the Grant Reduction Works, which company sunk several shafts, put up a concentrating mill, and shipped about 80 tons of zinc ore before forfeiting the bond. The main output has been of zine ore, and approximately 500 tons of mixed sulphide and carbonate ores are reported to have been shipped. Approximately as much more was in the stock piles at the time the mine was visited. In earlier years galena was taken from this crevice, but the amount is not known.

The mine is located on an east-west crevice which has been traced a mile or more along its course. The elevation of the curb of the 
pump shaft is 762 feet, as determined by aneroid. This shaft starts some feet below the base of the shales, and the present workings are in the beds of the Galena limestone lying above the flint. A drill hole on the property is reported to have encountered the oil rock at a depth of 228 feet, corresponding to an altitude of 534 feet above sea.

The main shaft follows a narrow crevice through solid dolomite into an opening, the base of which, as developed in the summer of 1903, was approximately 100 feet below the surface. The opening is covered with a firm cap rock which marks the upper Receptaculites zone already mentioned. Below the cap rock the opening, as first found and as yet shown in the western end of the property, is about 18 inches to 2 feet wide and 3 to 4 feet high. The sides show coarsely ribbed sandy dolomite, marked by solution cavities. The bottom of the opening is occupied by dolomite sand containing broken pieces of rock. Farther east along the crevice this loose material has been excavated to a depth of 35 feet, the crevice in that depth widening until it reaches an average of 10 to 12 feet from wall to wall, with a maximum width of 20 feet. This open cavity is several hundred feet long. In the lower 4 to 5 feet of the loose material the ore occurred, and at the west end of the stope similar ore may yet be seen. Both blende and zinc carbonate occur, though the latter is the more common. Minor amounts of galena are present, and iron sulphide occurs, though not in large amount. These minerals are found in broken pieces mixed with the sand, as coatings on the fragments of rock and the walls, and in small, flat sheets running into the walls along the bedding planes. Usually there is between the blende and the rock a thin film, 1 or 2 millimeters thick, of iron sulphide. Not infrequently this has been altered to limonite, an alteration proceeding from the wall rock toward the blende. The blende itself shows, on weathering, that it represents thin sheets deposited concentrically over the rough surfaces of the dolomite. It is often completely altered to smithsonite while retaining its original form. There are a number of small crevices intersecting the main one, and at such crossings the amount of galena present is said to increase.

Nothing certain is known as to the occurrence of lower ore horizons. The present work extends to only a few feet below water level and not to the horizons at which pitches and flats, if present, should be expected.

\section{LITTLE CORPORAL MINE.}

This is one of the best equipped mines in the district and is making regular shipments of ore. The plant consists of an 80-ton concentrating mill, a crosshead pump, hoist, air compressor, and two drills, the whole driven by gasoline power.

The mine is located on a well-developed east-west crevice (N. $89 \frac{1}{2}^{\circ} \mathrm{E}$.), upon which for one-half to three-fourths of a mile old workings are 
indicated by dumps. The present workings are connected with the surface by means of a shaft 110 feet deep. The curb of this shaft is slightly below the base of the Maquoketa shale and at an altitude of 763 feet. The oil rock is reported from a neighboring drill hole at 506 feet above tide. The workings are accordingly in the beds above the flints, which seem here not to extend as high in the formation as usual by a few feet. The workings are now along what is locally known as the first pipe-clay opening. Some work has been done 20 feet above this opening; but in general the upper ground showed very little ore, and this mine is exceptional in that considerable bodies of zinc ore are found where no large body of galena was taken from the upper ground.

At the time the mine was visited the lower drift was approximately 400 feet long. ' The opening varies from 8 to 12 feet in height, being closed usually by a firm cap rock in which the crevice is marked by a mere line. In places it could be seen that above the timbering there were chimneys connected with the opening. The drift varied in width from 6 to 16 feet. East of the shaft there seem to be two parallel crevices, one of which is not well marked to the west. The ore makes on first one and then the other, and east of the shaft is cut off by a bar of hard rock coincident with the crossing of a northsouth erevice. The walls show the normal cavernous dolomite. The pipe clay from which the opening is named is a thin parting of clay, not usually more than half an inch thick, but sufficiently impervious to have localized the flow of underground water and so to have caused the formation of the opening. Apparently water flowed along both its upper and lower surfaces.

The predominant ore mineral is blende, very little galena or carbonate being present. This is one of the cases of blende forming in quantity above the flats and pitches. The present work is 20 feet below the plane of permanent water, but is within the zone of oxidation, as shown by the brown color of the rock and sand. The usual thin film of iron sulphide occurs between the blende and the rock, and occasionally large crystals of pyrite occur. For this region, however, the ore is unusually free from iron sulphide. The concentrates are said to run from 50 to 60 per cent in zinc and 2 to 4 per cent in iron.

The tailings are unusually clean, and the ore does not need roasting and cleaning. As many as 14 tons of concentrates are said to have been produced in a single mill shift. The mill started in July, 1903, and has run more or less steadily since. The flow of water is steady, but the amount is not known.

\section{WEBER \& CRING MINE.}

This mine inciudes several shafts along a crevice running N. $85^{\circ} \mathrm{E}$. The top of the central working shaft is at an altitude of 813 feet. 
Lead is the only mineral shipped. The Dunkel \& Link, a similar lead prospect, is located near by.

VINEGAR HILL MINE.

In Vinegar Hill Township there are many old workings, and the area has produced a large amount of lead. Efforts are now being made to reopen several of these mines, among which is the Vinegar Hill mine. This is located in a small ravine running into Galena River, the top of the shaft being 33 feet below the base of the shale. The crevice runs east-west and has yielded galena at a depth of 29 feet. A new shaft is now being sunk, and a drift is being run to the east 10 feet below the old workings. A very neat and effective equipment, with a gasoline engine for power, was in operation when the plant was visited.

FOX RIVER VALLEY MINE.

At this mine old workings on an east-west crevice are being reopened. Two shafts, one over 95 feet and the other 65 feet, are open. The shafts begin a few feet below the base of the shale. Both galena and blende have been found in small quantity.

\section{OLDENBURG MINE.}

This, probably the best known of the mines near Galena, was not open in the summer of 1903 . There are two shafts, the lower 100 feet, and the upper 140 feet deep. The altitude of the lower is 800 feet and of the upper 830, the nearest exposure. of the base of the shale being 832 feet. This mine has been described by Chamberlin and by Grant. The latter visited it in the summer of 1902, and his description is as follows: ${ }^{a}$

This mine is along an east and west crevice, or rather along two nearly parallel crevices which unite toward the eastern part of the mine. The ore body is in a vertical sheet and is an example of the honeycomb deposits. The thickness of the sheet varies from almost nothing up to about 30 feet, and has been mined for about 800 feet in an east and west direction. A small amount of lead is present. Where small north and south crevices cross the main crevice there are usually larger and richer deposits of ore. The customary order of deposition in the cavities in this honeycomb deposit is a thin coating of marcasite followed by blende. Mr. Richard Kennedy informs me that the bottom of the mine, which is now about 100 feet under the top of the hill, is still 100 to 125 feet above the oil-rock horizon. Further work here will quite probably develop a series of flats and pitches above the oil rock.

\section{NORTHWESTERN MINE.}

The mine of the Northwestiern Lead and Zine Company is located near the Wisconsin boundary, not far from the Chicago and Northwestern Railway. The mine, which was visited in the summer of 1904, was developed in the preceding winter. The shaft, which is 92 
feet deep, is located at the base of the slope at the head of a small tributary of Galena River. The workings, which extend east and west for nearly 200 feet, are mainly in the top of the Platteville, immediately below the brown dolomite of the Galena. The oil rock proper is not well developed, but the upper member of the Platteville shows as a thin-bedded, nonmagnesian, fine-grained limestone with many thin partings of carbonaceous material. It has a thickness of 15 feet and is said to rest on an 18-inch bed of blue clay, below which is the "glass rock." A hole drilled through the latter yielded a flow of artesian water under considerable pressure.

The ore consists of thin sheets of blende developed along the partings of the rock and minor amounts of breccia found in connection with some northward-pitching fractures. The south pitches have not been found. At the east end of the drift a quartering crevice brings into the main vein an unusual amount of galena which makes in a rich flat. Very little iron pyrite shows in the mine. The workings are below water level, though oxidation extends down almost to them. There is a new and well-equipped mill on the property.

\section{CALIFORNIA OR SAND PRAIRIE MINE.}

This property is being opened up by the Royal Mining Company. It is located near the Mississippi River, at the extreme southern edge of the district, in a small ravine cutting back into the Niagara escarpment. In the vicinity are a number of old lead diggings, which were formerly worked by long adits driven in from the edge of the bluff. These mines were the scene of great activity from 1849 to 1855 , and at that time acquired the name "California diggings."

The Royal Mining Company has three shafts located on an eastwest erevice about halfway up the slope of the ravine which parallels the vein. No. 1 is the shallowest and was not visited. No. 2 starts in the Maquoketa shale and was sunk through 8 feet of that and then 147 feet into the Galena. There are two drifts from this shaft, the main one at 105 feet corresponding to a horizon slightly above the flint beds extending eastward under No. 3 shaft. For a distance of 600 feet along this drift more or less galena and blende have been won by both overhead and underhand stoping. The most interesting portion of this drift is immediately under the No. 3 shaft, which was being sunk at the time the mine was visited. At this point the drift was 6 to 8 feet wide, and to the east opened out into a large cave similar in all respects to those in which in early days the large finds of galena were made. This cave was full of water when first encountered, but the level had been somewhat reduced by pumping when visited. At the east en $\mathrm{d}$ it is about 12 feet wide and equally high. It narrows above to a mere crevice. Below, it was then filled with loose rock, sand, and chunks of ore. On the walls were patches of a thin coating of iron sulphide, over which both blende and galena had 
formed as a crust and in the form of irregular clusters of erystals resembling nothing so much as toadstools. These were commonly 3 to 6 inches in diameter and projected 2 to 4 inches from the wall. They seem to represent the free growth of crystals in a saturated solution. The individual crystals of galena were often of some size, as much as $2 \frac{1}{2}$ inches being measured on an edge. Apparently after their formation the conditions of the solution changed, since many of the galena crystals showed faces hollowed out to a true cup form as if by solution, and such surfaces were coated with a white material, doubtless lead carbonate. There was also a small development of zine carbonate by alteration from the blende, and a very general oxidation of iron in the rock, as shown by the red color of the walls and the sand.

The significance of these facts lies in the circumstance that this whole cave and its contents underlies nearly the entire thickness of the Maquoketa shale, as was shown in the section of No. 3 shaft then being sunk, following a drill hole, to facilitate the excavation of the ore. In the shale there was no sign of either crevice or ore, but in the dolomite overlying the cave a small crevice showing a very little blende and galena was found. These relations make it clear that under favorable circumstances large and important bodies may be found under even a very thick cover of the impervious shale, and also that under present conditions surface oxidizing waters occur in quantity in the same situation. The bearing of these facts will be later discussed.

Below the main drift a second was seen, 147 feet below the top of the Galena limestone, which, after being driven to the east 100 feet in a bar, was heading in soft ground underlying one of the underhand stopes of the main drift. From the behavior of the water it was inferred that there was a connection between the two. No flats or pitches had yet been encountered, though the lower level was at a horizon at which they occasionally occur.

\section{PERU OR BLACK JACK MINE.}

This is a well-equipped property, not now in operation. Between the years 1876 and 1882 it was a steady producer, shipping ore regularly to the Illinois Zine Company, with which its owners were affiliated. Recently a new mill has been erected and the mine was pumped out and examined preparatory to resuming work, but apparently the ore reserves were unsatisfactory, as the plant has been closed down. While the examination was being made for the owners the writer visited the property in company with the superintendent, Mr. Henry Ragge, who courteously supplied the accompanying record of a drill hole sunk some years before upon the property.

The shaft curb is at an altitude of 660 feet, corresponding to a horizon about 40 feet below the base of the Maquoketa. The workings 
examined, down to 135 feet in depth, are in the flint beds, and show a complicated system of pitches, beginning at about the top of those beds and extending down to the lowest horizon accessible. These pitches have a general course northwest to southeast, the pitch being to the northeast and southwest. They begin with the "second pipeclay opening." The pipe clay, which defines an ore horizon, is the usual clay parting along a bedding plane in the dolomite, and is barely 2 inches thick.

The ore is blende, occurring intimately mixed with iron sulphide. The latter is, within the limits open to observation, more abundant in depth at the north end of the property, though it is reported to be less abundant in the inaccessible lower levels. Near the top of the workings, 45 feet below the surface, cubes of galena three-eighths of an inch in size were found plentifully sprinkled over the blende. Additional cube lead was reported, though not seen, at least 60 feet below original underground water level. The ore occurs in thin sheets in the pitches and in flats along bedding planes. Sheets 6 inches thick were observed at a few points.

The occurrence of well-defined pitches and flats so high in the formation is somewhat unusual, and their evident former richness is very encouraging to prospectors working at still higher horizons in the crevices and openings.

The following drill record is of interest and value as showing the persistence of the zones recognized farther north. The carbonaceous shale near the base represents, probably, the oil rock of the mines farther north.

\section{Drill record at the Peru mine, Illinois.}

Clay and rock Ft. In.

Galena limestone, "sand rock"

Clay, called "second pipe clay," corresponding to the adit tinnel level

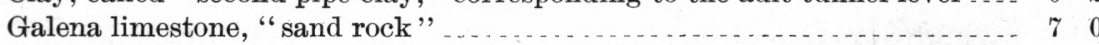

Clay, "third pipe clay" ... . . .

Galena limestone .............

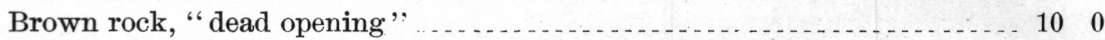

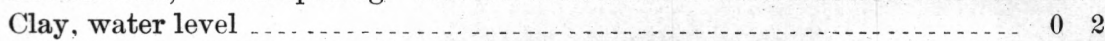

Galena limestone .......................... 110

Clay, "real pipe clay", $\ldots . . .6002$

Blue limestone opening, ore . . . . . . . .

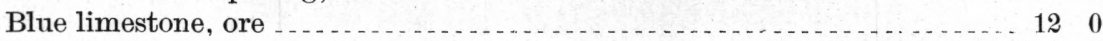

Cap over clay bed .............. 20

Clay ...

Blue to gray limestone........................... 04

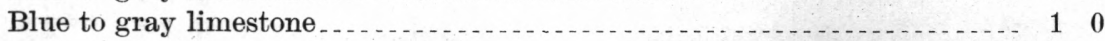

Shale with blende.

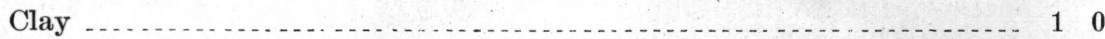

Blue to gray limestone $\ldots \ldots \ldots \ldots \ldots$

Blue limestone, hard brown $\ldots \ldots \ldots \ldots \ldots$

Glass rock proper

Carbonaceous shale $\ldots \ldots \ldots \ldots$ 
ue limestone $\ldots$

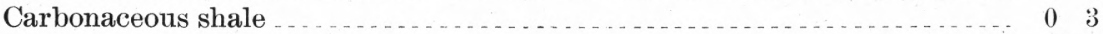

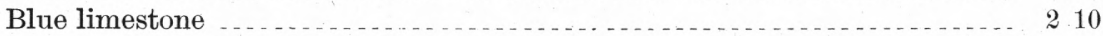

Bottom of shaft:

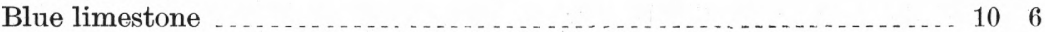

Shale ... . . . . . . . . . . . . . . . . . . . . . . . . . . 01

Limestone . . . . . . .

St. Peter sandstone.

WISHON MINE.

The Wishon mine, located a short distance north of Elizabeth, was an important producer of lead about 1865. In 1902 the old workings were reopened in a search for zine, and a new shaft was sunk 145 to 150 feet in depth. This was closed at the time the place was visited, but the former lead workings were reached by means of an old shaft near by.

The workings are developed along an important east-west crevice marked by old shafts for a distance of a mile along its course. The opening visited is in the Galena limestone, just above the flint beds. The ground shows thorough oxidation, and galena was the only mineral seen. It occurs in small pieces in tight crevices, the remaining ore evidently having been removed. There is a large amount of open ground with well-defined pitches both to the north and to the south running down into the flint beds. Apparently a considerable amount of ore has been taken from this ground.

APPLE RIVER MINE.

This mine is losated north of Elizabeth on a crevice which has been an important producer of lead. In the summer of 1903 an old shaft was being pumped out, but the workings were not sufficiently advanced to permit of any examination. The curb of the shaft is 75 feet below the base of the Maquoketa shales, and the crevice runs N. $71^{\circ}$ E. (true).

SKENE MINE.

This mine in 1904 was being reopened by the Elizabeth Mining and Milling Company. It is located on a crevice running N. $83^{\circ} \mathrm{E}$, the curb being at an altitude of 673 feet, corresponding to 40 feet below the base of the shales. It shows well-defined pitches to the north and south at a depth of 96 feet. The mine has been developed about 1,200 feet along the south pitch, with crosscuts to the north. The work is below present water level, but is entirely in oxidized ground. The ore consists of nearly clean galena. Minor amounts of pyrite are found, both as the usual film separating the galena from the rock and in distinct balls and erystals. No carbonate of zinc occurs, and only a very few very small pieces of blende. The ore is mainly 
in the south pitch, but numerous small flats and verticals run off into the core between the pitches, and possibly the whole of the core may be milled. There is no evidence that the galena in this case is a secondary concentration, and the amount of it, if it be original, is notable. Between May and August over 600,000 pounds were shipped without any cleaning facilities other than hand jigs.

QUEEN MINE.

This property is located near the city of Elizabeth, with the eurb of the shaft at 677 feet above sea, corresponding to 34 feet below the shales.

VISTA GRANDE MINE.

This is a small lead mine near Scales Mound and almost on the State line. The curb of the shaft is 40 feet below the top of the Galena, and the shaft is 115 feet deep.

\section{ORIGIN OF THE DEPOSITS.}

\section{GENERAL STATEMENT.}

Many hypotheses have been advanced to account for the origin of these deposits. The mines were among the earliest in America to record any considerable production, and their development has been coincident with that of the theory of ore deposits. The history of the various attempts which have been made to work out the story of their genesis is of considerable interest, but no attempt will be made in this place to go into it, nor will the writer attempt to say the final word as to their origin. Rather, a brief statement will be given as to principal theories now held by various workers in the field, with some consideration of the points of conflict and agreement.

\section{ORIGINAL SOURCE OF THE MATERIAL.}

There is now practically a consensus of opinion that for the source of the material from which the deposits were formed we must look to the ocean in which the rocks themselves were deposited. This ocean received débris from the adjacent land, and the ultimate source of the débris was the pre-Cambrian rocks, part of which are igneous. It was in them probably that the minerals reached the surface of the earth. The transfer of the lead, zinc, and associated minerals from the pre-Cambrian crystallines to the Ordovician dolomite was brought about entirely by the agencies of weathering, erosion, transportation, and deposition, in exactly the same manner in which the lime and magnesia of the country rock were transferred. The alternative hypothesis, that the materials were introduced into the sedimentary rocks at a later period as solutions, receiving their load in the heated interior of the earth, has been advanced, but has nothing in the field evidence to commend it. Where ore bodies have been formed by 
such a process they are, so far as observation goes, the accompaniment of igneous intrusions and of deformation, both of which are conspicuously absent in this area. Furthermore, lead and zinc deposits in the Western States which show any relation to igneous rocks are marked by a characteristic set of associated minerals, including complex compounds of arsenic, antimony, and silver, frequently by fluorspar, etc. None of these minerals have ever been reliably reported from this area. This alternative hypothesis may therefore be dismissed as not supported by local evidence and as based on analogy only.

It remains to inquire whether the material deposited in the Ordo.vician ocean was uniformly disseminated or locally concentrated. In favor of the former view it may be urged that the metals were doubtless brought to the ocean in solution, and it is of the nature of solutions to maintain uniformity of composition throughout their extent under uniform conditions. The sea, therefore, if it differed notably in composition from point to point, must have been so broken up by geographic conditions that there was not that free interchange of material by diffusion and convection from point to point which would establish uniformity in composition. Since the field evidence shows clearly that the deposits are localized and somewhat erratically distributed, this must therefore be referred either to geographic conditions at the time of the deposition of the ore or to later conditions operating to irregularly concentrate originally uniformly disseminated materials.

Chamberlin ${ }^{a}$ has worked out in detail one hypothetical set of conditions which, by virtue of operating to locally concentrate precipitating material, may well be appealed to in order to explain this irregularity. Calvin and Bain have suggested in less detail ${ }^{b}$ a set of geographic conditions which, by locally and irregularly concentrating the solutions of the metals, might have brought about the same irregular distribution of the disseminated material. Neither of these hypotheses is, at present at least, within the domain of investigation. They can hardly be either proved or disproved, and they are not necessarily contradictory. Van Hise, ${ }^{c}$ leaving open the question as to original regularity or irregularity of the distribution of material, appeals to conditions existing during the period of concentration to explain the present localization of the ore deposits.

\section{PROCESS OF CONCENTRATION.}

That the Galena limestone does contain, commonly at least, minute quantities of lead and zinc has been shown by both inference ${ }^{d}$ and

a Geology of Wisconsin, vol. 4, 1882, pp. 529-538.

$b$ Geol. Survey Iowa, vol. 10, 1900, pp. 566-575.

c Twenty-second Ann. Rept. U. S. Geol. Survey, pt. 2, 1902, pp. 33-49.

$d$ Chamberlin, op. cit., p. 538. 
direct test. $^{a}$. That these materials are taken into solution, are transported, and are redeposited by the ordinary underground waters of the region are facts susceptible of everyday observation. In these facts lies the basis of the process of concentration, and as to the essential nature of that process there is now no important disagreement. The general process seems to be one of the solution of the disseminated material, probably existing as sulphides,.its transportation as sulphates, and its redeposition as sulphides by the action mainly of organic matter in the rocks or brought in by other currents of underground water. Secondarily there are important reactions of the sulphides on the sulphates and a side cycle passing through carbonates. It is possible that other courses may be taken. For example, sulphides are somewhat soluble directly, particularly in the presence of sodium sulphide, $\mathrm{Na}_{2} \mathrm{~S}$, which, $\mathrm{u}_{1}$ n meeting oxygenated waters, would become sulphate and indirectly cause the precipitation of the sulphides balanced by it in the solution. In the one case the waters recently from the surface and with their supply of oxygen unexhausted would be dissolving waters. In the second case they would act as precipitating waters at first, and only after having oxidized the $\mathrm{Na}_{2} \mathrm{~S}$ would they take up their normal rôle of solution of the sulphides. The two processes may have acted together.

The manner in which this process worked to bring about the present ore bodies is open to some question. Chamberlin considered the underground circulation in the case of each group of mines to be essentially local. ${ }^{b}$ Van Hise, while recognizing the dominance of the local circulation in producing the prominent features of the present deposits, appeals to an earlier, widespread circulation to explain their localization. These may for convenience be considered separately.

\section{LOCAL CIRCULATION.}

The water which sinks into the ground at any point has a course downward, outward, and in part finally upward to some lower point of exit. It enters the ground charged with certain elements, notably oxygen, which, in order to remain in the ground, must enter into combination with some element. There are a large number of elements which are prepared to take up this oxygen, but for the present purposes most of these may be neglected and attention concentrated on the organic material buried in the rocks. This is the great final absorber of the oxygen brought in by the surface waters, and the final result of combination is the formation of carbon dioxide, which gives the water increased solvent power, as regards the country rock of this district. Incidentally the oxygen may, in the absence of the organic material, or to a minor extent in its presence, oxidize sulphides to sulphates, but it quickly drops them, since the organic mat- 
ter is almost everywhere present in amounts which, though small, are sufficient to demand all the oxygen in the water. The first work, then, of the descending water is the removal of the organic matter by the formation of carbon dioxide and the coincident solution of limestone or dolomite, with the formation of chambers, which later become the receptacles of ore. When the carbon has been removed the waters turn to such sulphides as may be present and oxidize them. In the form of sulphates, carbonates, etc., they are carried down to where organic matter is not yet exhausted and are redeposited. Thus, on the edge of the disappearing organic matter, sulphides appear in force, and back of sulphides are carbonates and oxides. The metals are thus arranged in order downward, corresponding to their affinity for sulphur and in reverse order of their affinity for oxygen. Lead, being least soluble in oxygenated waters and having the strongest affinity for sulphur, lags behind, and great masses of galena are found in the upper workings where surface waters have so long been dominant that they have completely broken down much of the wall rock and only a red dolomite sand remains. Below the galena is zine, in the upper levels earbonate with only traces of blende left, and below that blende with only traces of carbonate forming. Below the blende normally come the iron sulphides in greatest force, and still lower the zone of intimately mixed sulphides of all sorts, the zone in which the preponderance of organic matter is so great that all sulphides are protected from oxidation.

In the upper Mississippi district the boundary lines between the horizons of dominant blende, dominant iron sulphides, and mixed sulphides are not well marked. This is probably due to the fact that in most mines where these horizons have been studied they are crowded together within a few feet of the oil rock and occur in beds notably charged with organic matter. There seems also to be an unusual amount of iron sulphide present, and this perhaps obscures the relations. It is possibly significant that at the Little Corporal mine, where the blende is considerably above the oil rock and where organic matter is smaller in quantity, iron is distinctly less in amount. This is probably due to the opportunity afforded for the selective action of the oxygenated waters to come into play.

Undoubtedly the process outlined above has taken place, and to its action is due the prominent features of the ore deposits. Such a process does not, however, explain the localization of the ore bodies, and it does not at present seem that any adequate appeal can be made to local underground circulation to do this, since the opportunities for such circulation seem to be rather evenly distributed throughout the field. It has already been seen that the attempt to explain this localization on the basis of original conditions of sedimentation, while promising, stands for the present on no very certain ground. To 
meet these various objections Van Hise has suggested an earlier, widereaching circulation of artesian nature. ${ }^{a}$

\section{GENERAL ARTESIAN CIRCULATION.}

As has already been indicated, the area is one in which the underlying rocks consist of alternating dolomites and sandstones with a simple dip to the south and west. These sandstones carry water; which is under artesian pressure, ${ }^{b}$ and at an earlier period, before the Maquoketa shale was removed by erosion, it is quite probable that there was at least some similar circulation in the Galena limestone itself. The horizon now yields artesian water in territory farther south where the present conditions can not be greatly different from those supposed to have existed at an earlier date in the lead and zinc district. It is possibly significant that the water from the Galena at Davenport is notably impregnated with hydrogen sulphide, ${ }^{c}$ and that J. A. Udden has recognized pieces of zinc blende in the drillings of the Carbon Cliff well from the same horizon. ${ }^{d}$ Of possible significance also is the occurrence, recognized by Udden, of small films of zinc blende lining cracks in the nonmagnesian, dark-colored Devonian limestone near Rock Island, Ill., a point below which artesian water undoubtedly occurs in the Galena limestone under some pressure.

If this far-reaching circulation be appealed to in order to explain the first concentration of the ore deposits, waters similar to those now in the Galena limestone elsewhere are assumed to have become charged with salts of the metals while traversing the weathered extension of the formation to the northeast, and to have been carried downward along the dip, under the Maquoketa shale, to the area within which the present mines are located. Here the waters, under artesian pressure, are believed to have risen and outflowed at the point or points at which the shale was first cut through by the streams, and, meeting waters carrying different elements in solution, lost their load of metals by precipitation. In this way the material gathered in the weathering of a large area of Galena limestone to the northeast would be brought together and deposited in smaller areas where the shale was first cut through. These deposits of the first concentration were then reconcentrated, perhaps more than once, in the course of the gradual lowering of the surface, by the agencies and process already described. According to this view, concentration through and from beds lower than the Galena limestone is not excluded, though it is possible that the whole was confined to the beds between the Maquoketa and the shale at the base of the Platteville.

$a$ Twenty-second Ann. Rept. U. S. Geol. Survey, pt. 2, pp. 33-41.

b Norton, Geol. Survey lowa, vol. 6, 1897, pp. 113-428.

c Norton, op. cit., p. 273.

$d$ Seventeenth Ann. Rept. U. S. Geol. Survey, pt. 2, 1896, p. 836. 
A number of objections to this hypothesis present themselves. In the first place, it is not certain that the localization of the ore bodies conforms to the points at which there were the first or even the most important outlets for the artesian circulation. Just where the shale was cut through first can not now be positively affirmed. It is probable, though by no means certain, that these points were along the line of the present streams. It is quite possible that in the course of the development of the peneplain the streams may have been repeatedly shifted. In the second place, if one may judge from the mines now open, the evidence would seem to indicate that the circulation concerned in the formation of the ore was confined for the most part to the beds between the Maquoketa and the oil rock. Only a minor amount of circulation, even between the oil rock and the basal shale of the Platteville, seems to be indicated. At present there seems to be no connection between the water even of the St. Peter sandstone and that in the mines, ${ }^{a}$ and there is no good evidence of material having been brought up from lower horizons in the past. This notably narrows the applicability of the artesian hypothesis.

The Galena limestone when not weathered seems to everywhere contain small amounts of organic matter. While the percentage is not great, the proportion when measured against the possible content of the underground waters in the metallic salts is large enough to be effective. If, again, account be taken of the high reducing power of such material, given by Jenney at 18.04 to 40.67 in a scale in which hydrogen represents 100 , blende 8.25 , and galena $3.35,{ }^{b}$ it seems hardly likely that sulphates of these metals could be carried any great distance through this rock without precipitation. Furthermore, so far as analyses show, these deeper waters carry hydrogen sulphide in excess, and hence the sulphur present has probably, like the oxygen, entered into combination with the organic matter. If sulphates should meet such water they would be precipitated according to the following reactions : ${ }^{c}$

$$
\begin{aligned}
& \mathrm{PbSO}_{4}+\mathrm{H}_{2} \mathrm{~S}=\mathrm{PbS}+\mathrm{H}_{2} \mathrm{SO}_{4} \\
& \mathrm{ZnSO}_{4}+\mathrm{H}_{2} \mathrm{~S}=\mathrm{ZnS}+\mathrm{H}_{2} \mathrm{SO}_{4}
\end{aligned}
$$

It is supposable that in the presence of $\mathrm{Na}_{2} \mathrm{~S}$, and perhaps other substances, the metals, in the form of sulphides, might make the long: journey through rocks containing organic matter, but of such reactions there is no direct evidence. It seems probable, therefore, that the deeper circulation, to the extent that it was effective in the production of these ores, operated by furnishing the precipitating reagent rather than the material precipitated, and that the metallic sulphides enter-

$a$ Geol. Survey Iowa, vol. 10, 1900, p. $5 \% 6$.

b Jenney, Walter P., The chemistry of ore deposition: Trans. Am. Inst. Min. Eng., New Haven meeting, 1902, separate, p. 54.

$c$ Van Hise, op. cit., p. 39.

Bull. $246-04-4$ 
ing into the ore bodies came from the adjacent rock. Either or both of the postulated agencies may, therefore, have contributed to the localization of the ore bodies.

\section{FUTURE DEVELOPMENT.}

The limits within which prospecting should be confined have already been suggested. Topographically they extend from the base of the Niagara escarpment to the outeropping edge of the St. Peter sandstone. Stratigraphically they extend from the top of the Galena down to the oil rock, with a probability of a certain amount of ore being found between the latter and the base of the Platteville limestone. No development of recent years has shown anything warranting a revision of the opinions of Whitney, Chamberlin, and others that no important bodies of ore are to be found below the St. Peter sandstone.

The most productive horizons undoubtedly lie between the base of the flints and the oil rock, and it is in the pitches and flats that the larger bodies of ore are to be expected. Whether these lower horizons will prove as productive around the southern edge of the field, where they are under heavy cover, as in Wisconsin, where they come to the surface, is open to some question. Such evidence as is available points, in the author's judgment, to a favorable conclusion. The large lower workings in the Black Jack mine, where nearly the whole thickness of the Galena was penetrated, and the rich cave discovery in the California mine, under nearly the whole thickness of the Maquoketa and a hundred feet of the Galena, are certainly favorable indieations of great significance.

In the search for bodies of zinc ore the common practice is to locate where large bodies of lead ore are known to have been taken from old upper workings. This practice is founded on good principle, as has been already shown, and is heartily recommended. A careful attention to the stratigraphy of the district will enable any competent engineer to estimate very closely the distance to the oil rock, and hence the maximum depth to which he need drill or sink. With these guides, prospecting should be carried on with rather unusual economy. The patchy and irregular distribution of the ore in the upper levels should be kept constantly in mind.

In mining no unusual difficulties or expenses need be anticipated other than those incident to the opening of a district in which the labor is not accustomed to the new work. These difficulties may well be expected to entail considerable expense, but if anticipated they may be minimized. The pumping problem has been locally considered difficult, but if experienced labor be employed the difficulties will largely disappear. The maximum depth of mining is in most situations less than 200 feet. The amount of water handled has not been 
measured in many cases, but is known to be less than 500 gallons per minute in most cases. By bulkheading old drifts this may frequently be reduced, and by cooperation in the work such quantities ought not to entail either unusual trouble or great expense.

So far, the preparation of the ore for the market has caused the largest expense and the greatest difficulties, on account of the high content of iron sulphide. This problem is already being solved by attacks along several lines. By mixing the ore with a larger quantity of high-grade Joplin ore the smelters are able to use some of it without injury to their retorts. By saving the sulphur and making it into acid the iron sulphide becomes a source of revenue rather than a loss. By doing the roasting at the mine and cleaning the roasted concentrates by magnetic separators the miners widen their market. Finally, by the use of static electricity, now being experimented with and giving very hopeful results, ${ }^{a}$ it is possible that both the blende and the pyrite may be made into merchantable products.

In conclusion it may be stated that in the author's judgment the region contains large reserves of zinc ore of good grade, and the mines in Illinois may be expected to yield their due proportion to systematic prospecting and mining. The very favorable situation of the district as regards transportation facilities and fuel supplies may be expected to materially aid its development. 



\section{IN D EX.}

Page.

Aluminum, occurrence and character of - 24-25

Antimony, absence of

Apple River mine, location and character

$$
\text { of . }
$$

Arsenic, absence of .......................

Avenue Top mine, section in, diagram of Azurite, character of .....................

Bain, H. Foster. See Calvin and Bain.

Barite, character of ..................

Black Jack mine. See Peru mine.

Blende. See Zinc blende.

Blue Mounds, location of .

Buff limestone, occurrence and character of . . .

Calcite, character and occurrence of . ... . 28,30

California mine, location and character

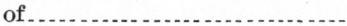

Calvin, Samuel, on Maquoketa shale and fossils

on Oneota dolomite.

Calvin, Samuel, and Bain, H. Foster, on geology of Dubuque County, Iowa

on Illinois Quaternary deposits......

on origin of zinc and lead deposits ...

Cambrian rocks, occurrence of . ....... 16-17

Cambrian time, conditions in............

Cerussite, character of .................

Chalcopyrite, character of ...............

Chamberlin, T. C., on depth of ore

on galena bodies ...........................

on Illinois Quaternary deposits. on Oldenburg mine

on order of deposition of minerals....

on ore deposits. .......................

on origin of zinc and lead deposits 45,46

on underground circulation .......... 46

Circulation, underground. See Underground circulation.

Clays, residual, occurrence and character

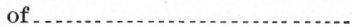

Cleidophorus neglectus, occurrence of...

Coal fields, map showing relations of Northwestern Illinois district to

Concentration of zinc and lead deposits, method of ..................... 45-50

Crevice, McNulty, section along, diagram of .............................

Crevices, location of, Whitney's map showing
Page.

Crevices, occurrence and character of ... 30-33 orein ............................. 33

Crider, A. F., acknowledgments to...... 9

Ctenodonta fecunda, occurrence of ...... 22

Deposition of minerals, order of ......... 29

Dolomite, character of ................ 28

Dubuque, Iowa, lead mines at .......... 11 ore shipments from . . . . . . . . . . . . . . . 10

Dubuque, Julien, lead mines opened by .. $\quad 10$

Dunkel \& Link prospect, location of ..... $\quad 39$

East Dubuque, Iowa, crevices in Galena limestone near, view of ...... 32

Elizabeth, Ill., mines near . . ........... 10,43

Elizabeth Mining and Milling Company, property of ................ 43

Ellis, E. E., acknowledgments to......... 9

Empress mine, plan and cross section of. 34

Fairview mine, lead shipment from ..... $\quad 9$

Flats, occurrence and character of . ..... 33-35

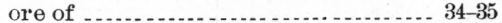

Fluorite, absence of

Fluorspar, occurrence of ............. 9

Fossils, occurrence of . . . . . . . . . 2........ 20-23

Foster, J. W., on Galena limestone and

Maquoketa shale .......... 20,21-22

Fox River Valley mine, character of .... $\quad 39$

Fulcher and Hancock, survey by ......... 34

Galena, character of .................. 27 occurrence of . ................. 10,29-30,33 order of deposition of ........... 29

Galena, Ill., mines at and near ..... 10,11,36,39 ore shipments from . .............. 10

terrace at......................... 24

view of ......... 24

Galena limestone, character of ....... 20-21,25

crevices in, views of ............... 32

formation of .................... 25-26

lead and zinc in . . . . . . $45-46$

occurrence of ................... 17,20

organic matter in . .................. 49

section of .

surface of, view of ............ 20

water in ......... 49

Galena zone, position of ...... 29-30

Galvanizing, spelter used for. . ........... 12-13

Gash veins. See Crevices.

Geologic history, sketch of . . . . . . . . 25-26

Geologic map of Northwestern Illinois district.................. 18

Geologic section of Galena limestone -... $\quad 21$

of Niagara formation . . .............. . 22

of Peru mine.............. $42-43$ 
Geologic section of Platteville limestone. of rocks in Northwestern Illinois....

Geologic structure, character of ......... 25,35 relations of ores and

Geology of Mississippi region, map show ing . .............................

Geology of Northwestern Illinois district, account of

Glass rock, occurrence and character of.

Grant, U. S., acknowledgments to on Illinois Quaternary deposits on oil rock . on Oldenburg mine on order of deposition of minerals.. on Wisconsin geology photograph made by

Gypsum, character of.

Hall, James, on Galena limestone

Halysites catenulatus, occurrence of ... Hancock and Fulcher, survey by ......... Hardin County, Ill., zinc and lead in .... Hayes, C. W., letter of transmittal by ... Hegeler, Matthiessen \&, zinc works built by

Hematite, character of

Hobbs, W. H on ore deposits.

Horizons, productive, positions of

Horseshoe Mounds, location of ..........

Hudson formation, correlation of .......

Hyolithes parviusculus, occurrence of...

Illinois, production of zinc in . ...........

Illinois Zinc Company, zinc works of ....

Ingalls, W. R., on zinc

Introduction.

Iowa, lead and zinc in.

Irving, R. D., on Oneota dolomite .......

Jenney, W. P., on underground waters.

Jo Daviess County, Ill., zinc and lead in .

Joints, occurrence and character of ...... ore in

Jonesboro, Ill., prospecting near

Joplin, Mo., zinc at .......................

Kansas-Missouri field, production of zinc in.

Kennedy, Richard, information supplied by

Kentucky, zinc shipments from .........

Kentucky - Illinois fluorspar, lead, and zinc field, mention of

Kirchhoff, Charles, on zinc ................

Lasalle, Ill., zinc works at ...............

Lead, lands containing, laws concerning. original source of . .................... production of, in Southern Illinois district

production of, history of ........... 10-11 shipments of

Lead deposits, concentration of ..........

Lead mining in Illinois, future of ........ 50-51

Leonard, A. G., on ore deposits. ..........

Leperditia fabulites, occurrence of.......

Le Sueur, lead discovered by ..............

Limonite, character of

Liospira, occurrence of ...................

Little Corporal mine, location and character of.
Loess, occurrence and character of ..... Page. Lower Magnesian limestone, equivalents of

Malachite, character of

MeGee, $\vee \sqrt{ } \mathrm{J}$, on Oneota dolomite.

McNulty erevice, section along, diagram showing

Map showing relations of coal fields and smelting centers to Northwestern Illinois district.......

Map, geologic, of Mississippi region ..... of Northwestern Illinois district.......

Maquoketa shales, character and occurrences of

Marcasite, character and order of deposition of . . . $27-29$

Matthiessen \& Hegeler, zinc works built by .......................... 11

Melanterite, occurrence of . . . . . . . . . . 28-29

Mineral Point, Wis., zinc works at. ...... 11-12 Mineral Point Zinc Company, works of.- 12

Minerals of district, character of ....... 27-29 modes of occurrence of . . . . . . . . . . $30-36$ paragenesis of . . . 2 29-30

Mines, average depth of . .............. 50

Mines and prospects, descriptions of . ... 36-44

Mississippi, mines in, production of ...... 13

Mississippi region, map showing geology of . .

Mississippi Valley, character of, in Northwestern Illinois district. . . .... 15-16 geologic history of ................ 16 lead and zinc field of, area of ........ 10 part of, in Northwestern Illinois district.

Missouri-Kansas region, production of zinc in ..........................

New Richmond sandstone, occurrence and character of ............ 17, 18

Niagara dolomite, character, occurrence, and section of ........... 22-23

Niagara epoch, conditions in . . . . . . . 25-26

Niagara escarpment, location and character of . ......... 14-15

Niagara formation, occurrence of ....... $\quad 17$

Northwestern Illinois district, area of . . 10

future of . . . . . . . . . . . . $50-51$

geologic map of . . . . . 18

lead from . . . . . . . . . . . . . . 10

location of . . . .

map showing relations of coal fields and smelting centers to ...... 9

zinc from ........................ 10

Northwestern Lead and Zinc Company, mine of . . . . 39-40

Northwestern mine, location and character of . . ... . . $39-40$

Norton, W. H., on elevation of Mississippi River bottom ................. 24

on Galena limestone................... 25

on New Richmond sandstone ......... 18

on underground waters.............. 48

Oil rock, relative position and character

\footnotetext{
of
of

Oldenburg mine, location and character

Oldenburg mine, location and character
}

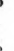

28

18

32

9

6

18

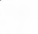

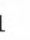

,

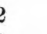

6

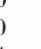

4

16

6

6

0

9

\section{3}

18


Page.

Oneota dolomite, occurrence of ......... 17,18 Openings, occurrence and character of . . 31-33

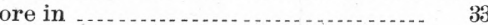

Ordovician ocean, zinc and lead in . . . . - 44-45 Ordovician rocks, occurrence of ... 16-17, 18-22 Ores of district, character and mode of occurrence of . . . . . . . . . 2 $27-36$ forms of $30-35$ relations of geological structure and. relations of topography and relations of water table and $35-36$

Orthis deflecta Conrad, occurrence of ... $\quad 20$ perveta Conrad, occurrence of . ..... 20 tricenaria Conrad, occurrence of .... 20

Orthoceras, occurrence of . ..............

Owen, D. D., on galena on Lower Magnesian limestone....... survey by

Peneplain, character of . . . . . . . . . . 14-15, 26 formation and age of . . . . . . . location of . . . . . 14-15

Perrott, Nicolas, lead discovered by ..... 10

Peru, Ill., zinc works at . ............... 12

Peru mine, character and output of .... 41-43 section at ........................ 42

Pitches, occurrence and character of . . . 33-35 oxe of . . . . . . . .

Platte Mounds, location of .............. 15

Platteville limestone, occur rance of .. 17, 18-20 section and character of

19-20

Pleurotomaria depauperata, occurrence of .

Pope County, Ill., zinc and lead in ....... 9 Potsdam formation, equivalents of . .... 17-18

Pre-Cambrian rocks, occurrence of . .... 16-17 original source of lead and zinc in ....

Fra-Cambrian time, conditions in ........

Prospecting area, limits of ................

Prospects and mines, descriptions of .....

Pumping, expense of. . . . . . . . . . . . . . . . .

Pyrite, character of . . . . . . . . . 2 .

Quaternary deposits, occurrence and character of ........... 17,23-25

Queen mine, location of ................ 44

Ragge, Henry, information supplied by _ 41

Ranges. See Crevices.

Receptaculites oweni, occurrence of .....

Residual clays, occurrence and character of - .

Rockdale, Iowa, galena limestone near, view of

Royal Mining Company, property of .....

St. Croix sandstone, equivalent of ........ 17-18

St. Peter sandstone, occurrence and character of ............... 17, 18

Saline County, Ill., zinc and lead in ......

Salisbury, R. D., on Illinois Quaternary deposits

Sand Prairie mine, location and character of

Schoolcraft, H. R., on lead mining ....... Section, geologic. See Geologic section.

Shakopee dolomite, occurrence and character of . .................. 17, 18

Shaw, James, on northwestern Illinois. .
Silurian rocks, occurrence and character of . .............. 16-17, 22-23

Silver, absence of ...................... 29

Sinsinawa Mound, location of . . . . . . 15

Skene mine, location, character, and output of .................... 43-44

Smelting centers, map showing relations of Northwestern Illinois district to

Smithsonite. See Zinc carbonate.

Southern Illinois district, fluorspar in ... . 9

lead and zinc from .................. . 9-10

Spalerite, character of ................. 27

Spelter, manufacture of . ............... 12

Stephenson County, Ill., galena in ....... 10

Stewart \& Bartlett mine, pitches in...... $\quad 34$

Terraces, occurrence and character of... 24

Tertiary time, conditions in . ........... 26

Todd, J. E., on scour .................... 25

Topography, relations of ores and ...... 35

of Northwestern Illinois district, account of . . . . . . 13-16

Trenton limestone, equivalents of _... . . 18-19

Udden, J. A., on zinc blende occurrence_ 48

Ulrich, E. O., acknowledgments to..... 9

Underground circulation, artesian, character and effects of .......... 48-50

Underground circulation, local, character and effects of . . ............ 46-47

Underground water level. See Water table.

United States, production of zinc in.....

Van Hise, C. R., on order of deposition of minerals

on origin of zinc and lead deposits _.. 45

on underground circulation ........ 46, 48

Vinegar Hill mine, location and character of ...................... 39

Vinegar Hill Township, mines in........ $\quad 39$

Vista Grande mine, location and character of ....................... 44

Wad, character of ..................... $\quad 28$

Water table, relations of ores and _..... 35-36

Waters mine, location, character of, and output of .................. 36-37

Weber \& Cring mine, location and character of ................. 38-39

White, C. A., on Maquoketa shale ...... 22

Whitney, J. D., map of ................ 36

on depth of ore bodies ........... 50

on Galena limestone............... 20

on lead mines..................... 11

on Maquoketa shale .................. 21-22

on northwestern Illinois geology ..... 16

on ore crevices . . ..... . . . . . . . . . . 30-33

on ore flats and pitches. ............. 33-35

Winchell, H. H., on Galena limestone... 25

Winslow, Arthur, on zinc . .............. 13

Wisconsin, lead and zinc in............. 10

Wisconsin Geological and Natural History Survey, survey by ....... 34

Wishon mine, location, production, and character of .............. 43

Zine, description of . .................. 12

history of .................. 10-13

original source of .................. $44-45$ 
Zinc, oxide of $\quad$ Page. percentage of, in zinc carbonate production of uses of

Zine blende, occurrence of order of deposition of paragenesis of use of

Zinc-blende zone, location of thickness of

Zinc carbonate, character of occurrence of. order of deposition of paragenesis of percentage of zinc in

30

$-13$

$9,13,30$
Page.

Zine carbonate zone, position of ....... 30 thickness of .......................... 36

Zinc ores, concentration of .............. 46 character and modes of occurrence of. $27-36$ forms of . ...... $30-35$ minerals of . . . origin of ................... $44-50$ paragenesis and order.of deposition of. 29-30 preparation of ........................ 51 production of .......................... 13 relations of geologic structure and... 35 relations of topography and......... 35 relations of water table and .......... $\quad 36$ Zinc mining in Illinois, future of ......... 50-51 Zinc sulphide. See Zinc blende. 